medRxiv preprint doi: https://doi.org/10.1101/2021.05.10.21256643; this version posted May 15, 2021. The copyright holder for this preprint

(which was not certified by peer review) is the author/funder, who has granted medRxiv a license to display the preprint in perpetuity.

It is made available under a CC-BY-NC-ND 4.0 International license .

\title{
PREVALENCE THRESHOLD THAT SHOULD BE APPLIED WHEN DECIDING SCHISTOSOMIASIS MASS DRUG ADMINISTRATION: SYSTEMATIC REVIEW AND META-ANALYSIS
}

Anthony Danso-Appiah ${ }^{1 *}$, Amadou Djirmay Garba ${ }^{2}$, Massimiliano Orso ${ }^{3}$, Kwadwo Owusu Akuffo $^{4}$, Fiona M. Fleming ${ }^{5}$, Guo Jiangang ${ }^{2}$, Pauline Mwinzi ${ }^{6}$, Daniel G. Colley ${ }^{7}$, M. Hassan Murad $^{8}$, Paul Hagan ${ }^{9}$, Paolo Eusebi ${ }^{3}$

${ }^{1}$ University of Ghana Centre for Evidence Synthesis and Policy (UGCESP), School of Public Health, P. O. Box LG13, Legon, Accra, Ghana

${ }^{2}$ Schistosomiasis Control Programme, WHO Department of Control of Neglected Tropical Diseases, Geneva, Switzerland

${ }^{3}$ Health Planning Service, Regional Health Authority of Umbria, Italy

${ }^{4}$ Department of Optometry and Visual Science, College of Science, Kwame Nkrumah University of Science and Technology, Kumasi, Ghana

${ }^{5}$ Schistosomiasis Control Initiative Foundation, Edinburgh House, 170 Kennington Lane, Lambeth, London SE11 5DP, UK

${ }^{6}$ Schisto and STH, ESPEN, AFRO, Brazzaville, Congo Brazzaville

${ }^{7}$ Center for Tropical and Emerging Global Diseases, University of Georgia, Room 330B Coverdell Center, 500 D.W. Brooks Drive -30602 - Athens Georgia, United States

${ }^{8}$ The Kern Center for the Science of Healthcare Delivery, Mayo Clinic, Rochester, Minnesota, USA

${ }^{9}$ Robert Gordon University, Garthdee House, Garthdee Road, Aberdeen, AB10 7QB, UK.

* Correspondence : Anthony Danso-Appiah, University of Ghana Centre for Evidence Synthesis and Policy, Legon, Accra, Ghana. Email: adanso-appiah@ug.edu.gh; tdappiah@yahoo.co.uk 
medRxiv preprint doi: https://doi.org/10.1101/2021.05.10.21256643; this version posted May 15, 2021. The copyright holder for this preprint

(which was not certified by peer review) is the author/funder, who has granted medRxiv a license to display the preprint in perpetuity.

It is made available under a CC-BY-NC-ND 4.0 International license .

\section{ABSTRACT}

\section{Background}

WHO-recommended prevalence thresholds for deciding schistosomiasis mass drug administration (MDA) are based on anecdotal evidence and unclear.

\section{Objectives}

This systematic review and meta-analysis, commissioned by the WHO as part of its new evidence-based guideline for schistosomiasis control, was to generate a single 'global' prevalence threshold that should be applied in MDA programmes worldwide.

\section{Methods}

We searched several databases from 1979 to $31^{\text {st }}$ March 2021 without language restriction. Two reviewers selected studies, extracted data, and assessed risk of bias using relevant risk of bias tools, and resolved disagreements through discussion. The review followed the PRISMA guidelines. Data were analysed and presented as prevalence reduction (PR) and relative risk (RR) for dichotomous outcomes or mean difference for continuous outcomes with their $95 \%$ confidence intervals (CIs). Meta-regression of observations on prevalence rates and intensity of infection of MDA programmes and sensitivity analyses to test the robustness of the results to the risk of bias components were performed. Evidence on benefits, harms, values, preferences, compliance, acceptability, equity and feasibility were also assessed. The overall level of evidence was graded using GRADE.

\section{Results}

Out of 1,232 studies retrieved, 38 studies met our inclusion criteria and 34 studies were included in the meta-analysis. No direct relation was observed between prevalence and intensity of infection. Praziquantel reduced prevalence of $S$. haematobium in school age children (SAC) at 12 months (RR $0.38,95 \%$ CI 0.28 to $0.52 ; 8$ studies, $\mathrm{n}=37,868$ ); at 24 months (RR $0.30 ; 95 \%$ CI 0.30 to $0.52 ; 7$ studies; $\mathrm{n}=37,107$ ); and 36 months (RR $0.39,95 \%$ CI 0.21 to $0.71 ; 5$ studies, $\mathrm{n}=28,146)$. There was no significant reduction in prevalence at 48 months ( 2 studies, $\mathrm{n}=10,954)$. For $S$. mansoni, there were reductions in prevalence at 12 months (RR 0.56, 95\% CI 0.46 to 0.69; 14 studies, $\mathrm{n}=86,073$ ); 24 months (RR 0.46; 95\% CI 0.32 to $0.66 ; 14$ studies; $\mathrm{n}=83,721$ ); 36 months (RR $0.44,95 \%$ CI 0.33 to $0.58 ; 7$ studies, $n=70,933$ ) and 48 months (RR $0.25,95 \%$ CI 0.11 to $0.59 ; 5$ studies; $\mathrm{n}=27,483$ ). Further analyses were performed from a series of created prevalence thresholds of $5 \%, 10 \%, 15 \%, 20 \%, 30 \%$ and $\geq 40 \%$ showed differences in effect of MDA when each of the thresholds was applied. For annual MDA of school age children (SAC), school-based treatment (SBT) appeared to perform better than community-wide treatment (CWT) in terms of prevalence reduction. Using the same prevalence threshold for the different schistosome species, the model suggested, that it will take a shorter time to reach elimination for $S$. haematobium than S. mansoni; annual MDA using SBT approach for S. haematobium will require about 10 years to achieve elimination whereas it will take over 10 years to around 15 years to achieve elimination for $S$. mansoni.

\section{Conclusion}

The evidence presented in this systematic review and meta-analysis suggests that $10 \%$ prevalence should be used as the 'global' threshold for implementing MDA in endemic countries. 
medRxiv preprint doi: https://doi.org/10.1101/2021.05.10.21256643; this version posted May 15, 2021. The copyright holder for this preprint

(which was not certified by peer review) is the author/funder, who has granted medRxiv a license to display the preprint in perpetuity.

It is made available under a CC-BY-NC-ND 4.0 International license .

\section{BACKGROUND}

The ultimate goal of schistosomiasis control is to prevent new infection or transmission by interrupting the parasite's lifecycle. This goal has been difficult to achieve; therefore, WHO guidelines have changed several times over the years from selective treatment (i.e. screening entire populations and treating positive cases), morbidity control focusing on symptomatic individuals or those with heavy worm loads and likely to suffer infection-related complications, passive case finding (push for hospital attendance by individuals with schistosomiasis-related symptoms) to Preventive chemotherapy (PC) adopted in the new millennium at the World Assembly (WHA54.19) in 2001 (WHO 1985; WHO 1993; WHO 1998; WHO 2002; WHO 2006; WHO 2012a; WHO 2012).

Within the PC concept, backed by resolution WHA54.19, endemic countries were urged to embark on mass drug administration (MDA) with Praziquantel (PZQ) at a single $40 \mathrm{mg} / \mathrm{kg}$ oral dose to treat at least $75 \%$ of school-aged children at risk of the infection (WHO 2002). WHO experts met and developed operational guidelines from Resolution WHA54.19 with emphasis on morbidity control, using defined thresholds of infection prevalence as criteria for classifying atrisk populations, and selecting appropriate intervals of mass MDA (WHO 2002). Schools-based MDA was identified as the most cost-effective strategy. Since then, millions of school-going children living in endemic countries have received multiple treatments with PZQ. The governments of endemic countries and international non-governmental organizations, including the Schistosomiasis Control Initiative (SCI), the Schistosomiasis Consortium for Operational Research and Evaluation (SCORE), both funded by the Bill and Melinda Gates Foundation, the United States Agency for International Development (USAID) the British Department for International Development (DFID and the Global Network for Neglected Tropical Diseases have been key in delivering MDA (Fenwick A et al. 2009; Hotez 2009, 2011; Linehan et al. 2011; King et al. 2020).

In 2006, the operational details of the PC strategy were revised (WHO 2006) to expand the target population for MDA to include adults and special risk groups, for example, occupationally exposed individuals in high-risk areas. In 2012, new goals (intensity-based not aligned to the prevalence-based thresholds) aimed to control morbidity and eliminate schistosomiasis as a public health problem using appropriate diagnostic criteria were set. It also specified that tools needed for routine testing should be sensitive and easy to use, should be able to demonstrate the presence of the parasite or marker of current infection, and should easily be adapted for use in peripheral health facilities with minimum cost and resource capacity. The WHO also urged member states to increase control effort towards elimination (WHO 2012a). At the same time, the NTD road map and the London Declaration of NTD encouraged partners to pledge commitment towards reaching up to $100 \%$ of school-aged children living in endemic regions by 2020 and to eliminate the disease in some regions (WHO 2012b; Uniting to Combat NTDs 2012). PZQ donation was to exceed 250 million tablets per year, and Countries and Programme Managers were encouraged to deliver the medicine to all at-risk populations at frequencies determined by the prevalence of infection.

Resolution WHA65.21 called WHO to develop guidelines for countries to embark on elimination programs and provide tools to document progress (WHO 2012). It also requested WHO to develop procedures to evaluate the interruption of transmission and certify that schistosomiasis transmission has been eliminated. Further goals and targets of the Strategic Plan recommended appropriate diagnostic approaches and tools for mapping control programmes and to verify interruption of transmission. Appropriate tools are to be selected at each stage of progress 
towards the elimination of the disease. The test should be sensitive, easy to use in the field and be able to categorize communities according to risk profiles, taking into account likely compliance in providing specimens. Ideally, in Africa settings, the test should be able to differentiate schistosome species since most areas are co-endemic and show mixed infections in individuals.

Given that the scaling up of schistosomiasis control through PC has significantly brought down prevalence and intensity of infection in most endemic settings to levels such that routinely used diagnostic tests are no longer sensitive to detect the infection or monitor the progress of control, CCA test was endorsed as representing an effective tool for the detection, monitoring and evaluation of $S$. mansoni control programmes (WHO Strategic Meeting in Geneva). The endorsement followed evidence generated from WHO-commissioned systematic review and meta-analysis that assessed the comparative accuracy of Point-of-care Circulating Cathodic Antigen (POC-CCA) and existing tools (Danso-Appiah et al. 2016; Barenbold et al. 2018).

The current thresholds for PZQ MDA are based on anecdotal data of prevalence in school-aged children $>=50 \%$ by parasitological methods (for intestinal and urogenital schistosomiasis) or $>=$ $30 \%$ by questionnaires for history of haematuria or $>=60 \%$ by CCA in S. mansoni. Within the MDA strategy, all school-aged children (enrolled or not) should be treated once a year. Adults from special groups to entire communities living in endemic areas considered to be at risk, should also be treated. Additional interventions should include improved water and sanitation, hygiene education (WASH) and snail control. For baseline prevalence among school-aged children $>=10 \%$ but $<50 \%$ by parasitology (for intestinal and urogenital schistosomiasis) or $<30 \%$ by questionnaire for history of haematuria or $>=15 \%$ but $<60 \%$ by CCA in $S$. mansoni endemic areas, all school-aged children (enrolled or not) should be treated once every two years; at least $50 \%$ of this age group should be treated each year). Within this strategy, adults considered to be at risk should be treated and additional interventions such as the provision of wholesome water, sanitation and hygiene education (WASH) and snail control should be combined with MDA. If prevalence is $<10 \%$ by parasitological methods (intestinal and urogenital schistosomiasis) or $<15 \%$ by CCA in $S$. mansoni endemic areas, all school-aged children (enrolled and not enrolled) should be treated twice during their primary school age, at least $33 \%$ of this age group each year. Water, sanitation and hygiene education (WASH) and snail control should complement the control effort.

Until now, the WHO guidelines for guiding the threshold at which MDA should be done had been based on anecdotal evidence and consensus rather than systematically synthesized evidence. This systematic review was commissioned by the WHO to find a global prevalence threshold that should be used to implement MDA with maximum benefit in high, moderate and low schistosomiasis endemicity settings.

\section{REVIEW METHODS}

\section{Criteria for considering studies for this review}

\section{Types of studies}

Published and unpublished studies, comparative and non-comparative, involving PZQ MDA alone or in combination with other medicines employed in the PC strategy or commonly used in PC settings, that evaluated benefits for any of the schistosomiasis species (S. mansoni, $S$. japonicum, S. intercalatum, S. mekongi or S. haematobium), were eligible for inclusion. Selective treatment studies, non-human studies, commentaries and reviews were excluded. 
medRxiv preprint doi: https://doi.org/10.1101/2021.05.10.21256643; this version posted May 15, 2021. The copyright holder for this preprint

(which was not certified by peer review) is the author/funder, who has granted medRxiv a license to display the preprint in perpetuity.

It is made available under a CC-BY-NC-ND 4.0 International license .

\section{Participants}

Whole population or subgroups (preschool-aged children, school-aged children, adolescents and adults, including pregnant and lactating women) infected with any human schistosome species or non-infected persons living in endemic areas who received PZQ (any brand) at a single dosing schedule $(40,50,60,70$, or $\geq 80 \mathrm{mg} / \mathrm{kg})$ during MDA were eligible for inclusion.

\section{Intervention}

Praziquantel at a single oral dose of $40,50,60,70$ or $\geq 80 \mathrm{mg} / \mathrm{kg}$, or in combination with Albendazole, Mebendazole, Pyrantel pamoate or Levamisole (for soil-transmitted helminthiasis), or Albendazole plus either Ivermectin or Diethylcarbamazine [DEC] (for Lymphatic filariasis), Artemisinin-based combination therapies (ACTs) for malaria, or Azithromycin (Zithromax) for trachoma.

\section{Control}

For dose comparisons, PZQ at $40 \mathrm{mg} / \mathrm{kg}$.

\section{Outcomes}

\section{Primary}

- Prevalence of infection or percent reduction in prevalence at 1, 3, 6, 12 or 24 months.

\section{Secondary}

- Intensity of infection or percent reduction of egg count at 1, 3, 6, 12 and 24 months. Intensity of infection was classified as light (100 epgs), moderate (100-399 epgs) and heavy ( $\geq 399$ epgs) for Kato-Katz, respectively, and light $(<50)$ heavy $(\geq 50)$ eggs per 10 $\mathrm{ml}$ of urine.

- Transmission of infection or percent reduction in transmission at 1, 3, 6, 12 or 24 months.

- Compliance, acceptability, preferences, equity and feasibility of the intervention strategy.

Adverse events

- Serious adverse events were defined as any event that required hospitalization or prolongation of existing inpatients hospitalization, life threatening, presented with significant disability/ incapacity or led to congenital anomalies or birth defects.

- Non-serious events were defined as mild to moderate and/or transient events.

\section{Search strategy for identification of studies}

We identified all relevant studies regardless publication status (published, unpublished, in press, and ongoing). We searched PubMed, EMBASE and LILACS from 1979 to $31^{\text {st }}$ March 2021 without language restriction. We searched the Cochrane Infectious Diseases Group Specialized Register, CENTRAL (The Cochrane Library 2021), mRCT, Hinari, Africa Journals Online and Google Scholar. Experts in the field of schistosomiasis were contacted for additional or unpublished data and the reference lists of articles were reviewed. The following search terms were used: schistosomiasis) OR schistosoma) OR schistosome) OR "schistosoma mansoni") OR "schistosoma haematobium”) OR "schistosoma hematobium”) OR “schsitososoma japonicum”) OR “schistosoma mekongi”) OR "schistosoma intercalatum”) AND praziquantel) OR biltricide) OR distocide) OR pharmamed) OR Bilharzid) OR Prazitel) AND "preventive chemotherapy") 
medRxiv preprint doi: https://doi.org/10.1101/2021.05.10.21256643; this version posted May 15, 2021. The copyright holder for this preprint

(which was not certified by peer review) is the author/funder, who has granted medRxiv a license to display the preprint in perpetuity.

It is made available under a CC-BY-NC-ND 4.0 International license .

OR "mass treatment") OR "mass drug administration") OR MDA) OR "blanket treatment") AND "endemic setting") OR "endemic community") OR "endemic country").

\section{Study selection}

One reviewer screened the results of the search output to identify studies meeting the prespecified inclusion criteria using a pre-tested study selection form. Full study reports of potentially relevant studies were obtained and checked against the predefined inclusion criteria, which were verified independently by the lead reviewer. Any discrepancies were resolved through discussion between the reviewers.

\section{Data extraction and management}

Two reviewers extracted data using a pre-tested data extraction form. Data extracted included study characteristics such as the country and year in which the study was conducted, the study design type as well as epidemiological and demographic characteristics - e.g., baseline endemicity, target population or subgroup that received MDA, age and number of participants involved in the MDA. We also extracted post MDA outcome data such as prevalence, egg count reduction, compliance and acceptability, equity and feasibility of treatment. We contacted some authors to see if they could clarify or supplement the results or provide raw data that we could use. If two or more communities were involved in a study, data were extracted for each community - with a link to the parent study. However, where it is not possible to separate the data by country or community, the combined data was used and presented as one study and the countries or communities in which the study was conducted were shown. Any discrepancies were resolved through discussion between the reviewers.

\section{Assessment of risk of bias in the included studies}

One reviewer assessed the risk of bias in each of the included trials using risk of bias tool for Randomized Controlled Trials (RCTs) (Higgins et al. 2011) and verified independently by another reviewer. Where information in the trial report was unclear, we contacted the trial authors for clarification. We assessed the risk of bias for six domains: sequence generation, allocation concealment, blinding (investigators, outcome assessors and participants), incomplete outcome data, selective outcome reporting and other sources of bias. For each domain, we made a judgment of 'low risk' of bias, 'high risk' of bias or 'unclear' risk of bias. ROBINS-I (Risk Of Bias In Non-randomised Studies- of Interventions), was used to evaluate risk of bias in estimates of benefit of interventions from studies that did not use randomization to allocate individuals or clusters of individuals to comparison groups (Sterne et al. 2016). Seven domains through which bias might be introduced into non-randomized studies of intervention (NRSI) were considered. The first two domains, covering confounding and selection of participants into the study, addressed issues before the start of the interventions. The third domain addressed classification of the interventions themselves. The other four domains addressed issues after the start of interventions: biases due to deviations from intended interventions, missing data, measurement of outcomes, and selection of the reported result. The STROBE checklist was used to examine the reporting of comparative observational studies (Von Elm et al. 2007) and PRISMA for systematic review and meta-analysis (Moher et al. 2009). The Risk of Bias Tool for Prevalence Studies (Hoy et al. 2012) was used to assess the methodological quality and risk of bias for each prevalence study.

\section{Data synthesis}

Prevalence and absolute rate of events were calculated from all studies and relative risks from comparative trials. Data were analysed and presented as prevalence ratios with their 95\% CIs. 
medRxiv preprint doi: https://doi.org/10.1101/2021.05.10.21256643; this version posted May 15, 2021. The copyright holder for this preprint

(which was not certified by peer review) is the author/funder, who has granted medRxiv a license to display the preprint in perpetuity.

It is made available under a CC-BY-NC-ND 4.0 International license .

The $\mathrm{R}$ software was used for the analyses. Random effects model was used with the metacommand for pooling data on treatment effect between baseline and first observation after MDA. Generalized linear mixed models were used for the meta-analysis and meta-regression of observations on prevalence rates of schistosomiasis before and after MDA. To this purpose the lme4 package was used. Data were extracted to get the maximum level of details. In the case of available information, each data row was an area within a study with a specific treatment for age group. The model contains random intercepts (the study units clustered within studies) and a random slope in time. This means that the rate at which schistosome infections declines after treatment is different from study-unit to study-unit. If a study unit has a negative random effect, then it decreases more quickly than the average. Whenever appropriate, we optimized the random effects, and the fixed-effects coefficients in the iteratively reweighted least-squares step by optimizing the parameter estimation. Wald $95 \%$ confidence intervals (95\% CI) were derived. A p-value less than 0.05 was considered significant in all the analyses.

\section{Heterogeneity}

We inspected forest plots for overlapping CIs and outlying data, and where heterogeneity was suspected, we conducted quantitative assessment from the Cochran's Q test and $I^{2}$ statistic, setting the $\mathrm{Chi}^{2}$ test at a more sensitive threshold (P-value $<0.1$ ) to indicate statistically significant heterogeneity (DerSimonian and Laird 1986; Bossuyt et al. 2013). The $I^{2}$ statistic, defined as the proportion of variation across studies that is due to heterogeneity rather than chance, was particularly emphasised, with proportions $>50 \%$ considered as substantial heterogeneity. Where significant heterogeneity was detected, we carried out subgroup analyses based on clinical and methodological differences between the included studies.

\section{Sensitivity analysis}

Where data were sufficient, we conducted sensitivity analyses to assess the robustness of the results to the risk of bias components. We used quality dimensions assessed from GRADE and risk of bias assessment to conduct sensitivity analyses by excluding studies considered to be of low quality to explore the robustness of our findings to these factors.

\section{Summary of findings and Grading the evidence}

We used GRADE (Alonso-Coello et al. 2016) to grade the evidence by looking at 5 main factors that might decrease quality of evidence, 1) study limitations, 2) inconsistency of results, 3) indirectness of evidence, 4) imprecision, and 5) publication bias. We also looked at factors that might increase quality of evidence including, 1) large magnitude of effect, 2) plausible confounding, which would reduce a demonstrated effect, and 3) dose-response gradient (http://www.gradeworkinggroup.org/).

\section{Evidence-to-recommendation}

WHO commissioned this systematic review and meta-analysis to support its guideline for guiding schistosomiasis control. As a result, we did an evidence-to-recommendation assessment on the following domains: benefits and harms - required an evaluation of the absolute effects of both benefits and harms of the intervention and their importance where greater net benefit and lower net harm associated with the intervention received a strong recommendation in favour of the intervention; values and preferences - described the relative importance assigned to health outcomes by those affected by them, how such importance varies within and across populations and whether this importance or variability is surrounded by uncertainty. The less uncertainty or variability around the values and preferences of people experiencing the critical or important 
medRxiv preprint doi: https://doi.org/10.1101/2021.05.10.21256643; this version posted May 15, 2021. The copyright holder for this preprint (which was not certified by peer review) is the author/funder, who has granted medRxiv a license to display the preprint in perpetuity. It is made available under a CC-BY-NC-ND 4.0 International license .

outcomes, the greater the likelihood of a strong recommendation; acceptability - the greater the acceptability of an option to all or most stakeholders, the greater the likelihood of a strong recommendation; resource use - pertaining to how resource-intense an intervention was, whether it was cost-effective and whether it offered any incremental benefit with the more advantageous or clearly disadvantageous the resource implications were, the greater the likelihood of a strong recommendation either for or against the intervention; equity and human right - the greater the likelihood that the intervention reduced inequities, improved equity or contributed to the realization of one or several human rights as defined under the international legal framework, the greater the likelihood of a strong recommendation; and feasibility - the greater the feasibility of an option from the standpoint of all or most of stakeholders, the greater the likelihood of a strong recommendation considering an overlap of feasibility with values and preferences, resource considerations, existing infrastructures, equity, cultural norms, legal frameworks and many other considerations.

\section{RESULTS}

\section{Description of studies}

The search retrieved 1,232 studies, of which 1186 studies were obtained from electronic databases and 46 studies from other sources, including grey literature and contacts with experts. After screening the search returns 1,204 studies were excluded. Fifty-one studies were excluded because of duplication, 1094 studies were not relevant to the topic, 49 studies were excluded because they were either non-MDA, reviews or did not provide treatment. 38 studies met our inclusion criteria, but four were excluded from the analysis because they had only baseline data. Of the 34 studies included in the analysis, $15 \mathrm{~S}$. mansoni and S. haematobium. No study investigated the other schistosome species (Fig. 1). All the MDA campaigns were done in Africa between 1988 and 2020 (Table 1). 


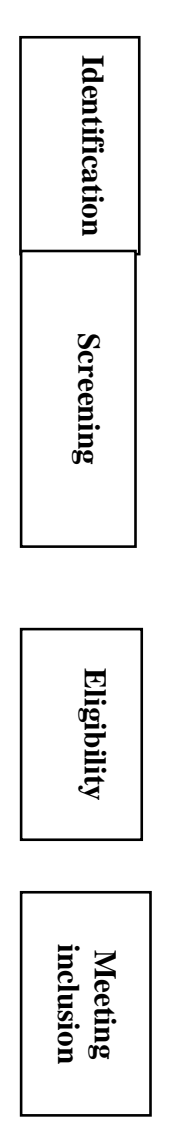

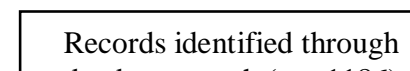

database search $(n=1186)$
Additional identified through other sources (46)
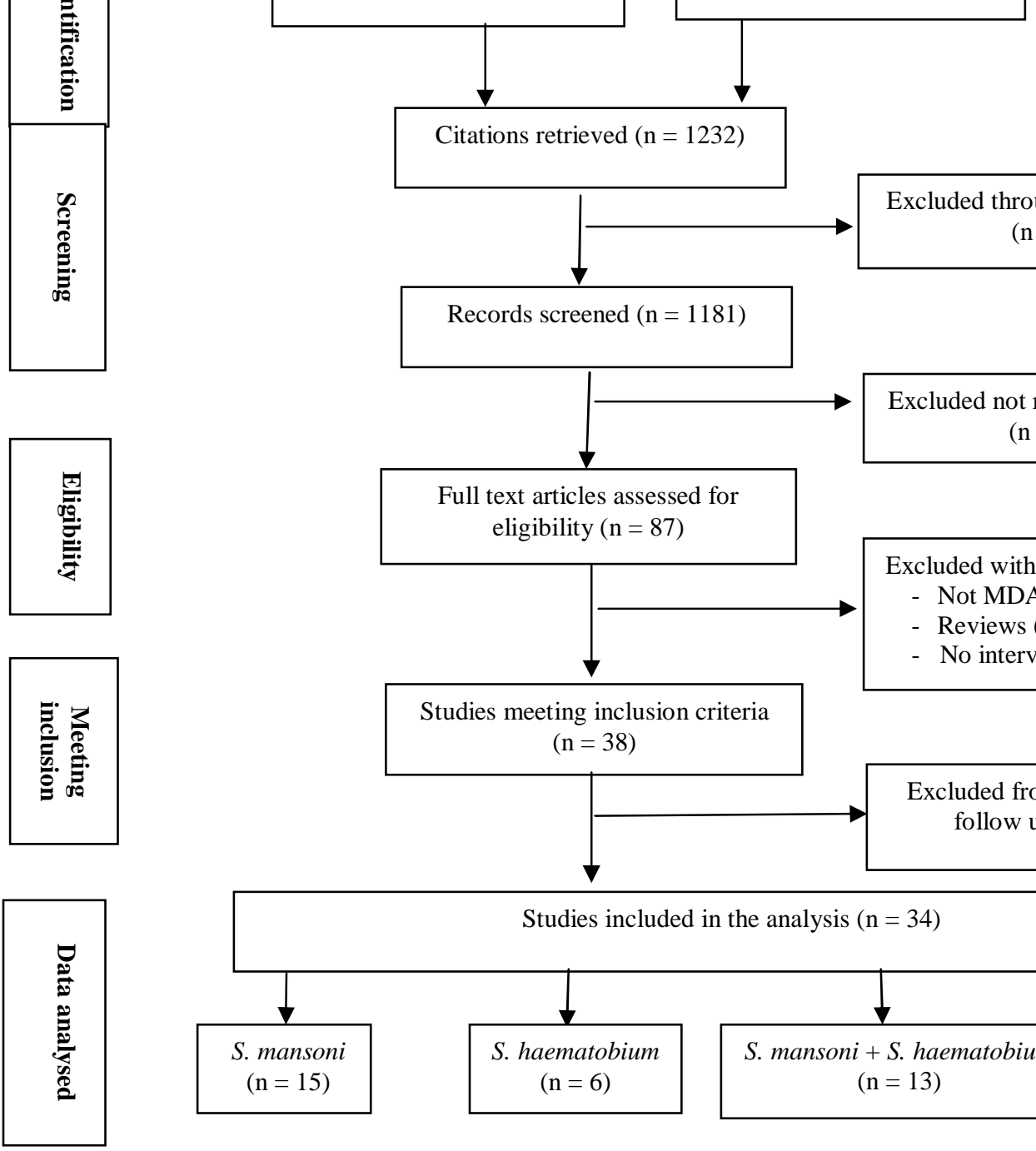

Citations retrieved $(n=1232)$

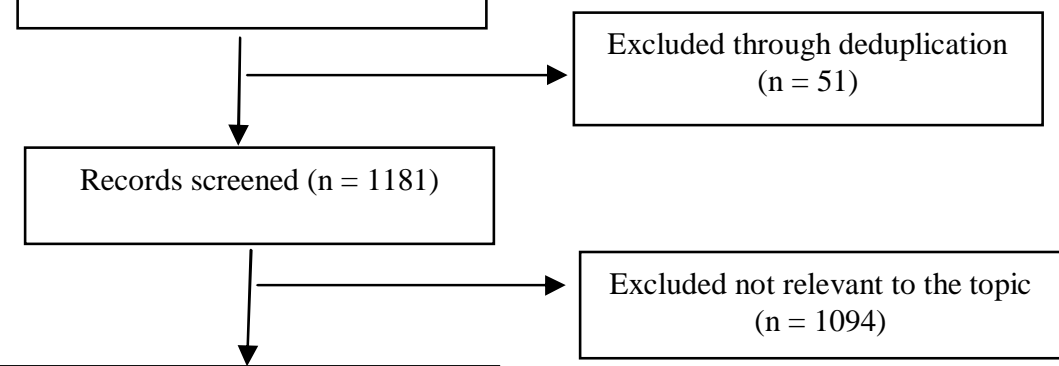

Full text articles assessed for eligibility $(n=87)$

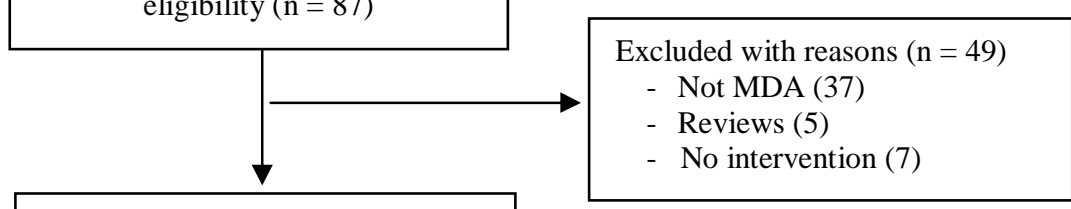

Studies meeting inclusion criteria $(\mathrm{n}=38)$

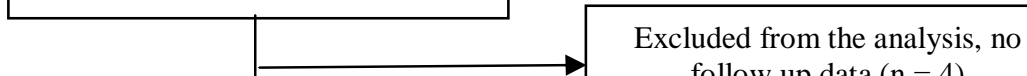
follow up data $(n=4)$

Fig. 1 Flowchart of studies retrieved from relevant electronic databases and other sources (including contacts with an expert in the field), number meeting the inclusion criteria and number included in the analysis by schistosome species. 
medRxiv preprint doi: https://doi.org/10.1101/2021.05.10.21256643; this version posted May 15, 2021. The copyright holder for this preprint

(which was not certified by peer review) is the author/funder, who has granted medRxiv a license to display the preprint in perpetuity.

It is made available under a CC-BY-NC-ND 4.0 International license .

\section{Study settings and participants}

Of the 34 studies included in the analysis (Table 1), 15 were conducted in West Africa (Sierra Leone $=3$, Burkina-Faso $=2$, Cote d'Ivoire $=2$, Mali $=2$, Niger $=2$, Senegal $=2$, Liberia $=1$ and Togo $=1$ ), fourteen studies were conducted in East Africa (Kenya $=8$, Tanzania $=3$, Uganda $=2$ and Ethiopia = 1), 6 studies were conducted in Central and Southern Africa (Burundi = 1, Malawi $=1$, Mozambique $=1$, Namibia $=1$, Rwanda $=1$, Zimbabwe $=1$ ) and two studies from North Africa, all conducted in Sudan. Shen et al. (2019) conducted a two-country study in Kenya and Tanzania and reported combined data. Twenty-six studies assessed PZQ alone and eight assessed PZQ combined with Albendazole. Twenty-eight studies involved school-aged children (SAC) and six involved SAC and adults. No MDA has been delivered to adults only. For the detection of the infection, 15 studies that involved people infected with S. mansoni used KatoKatz (KK), 6 that involved S. haematobium used urine filtration (UF), and 13 studies that involved mixed infection with S. mansoni and S. haematobium employed KK and UF. Only one MDA of $S$. mansoni infection from Uganda used KK and Circulating Cathodic Antigen (CCA) test. Follow-up time after MDA ranged from 6 months to 9 years (Table 1). Mode of delivery of MDA differed between studies: majority of studies delivered annual PZQ MDA least two years, some delivered MDA twice a year (bi-annual) and for some studies, MDA was delivered every two years (biennial). Some studies delivered annual MDA for two years and assessed effect of the treatment after 5 years so that three years elapsed after the last MDA before the outcome of treatment was assessed and some studies alternated MDA with drug holidays.

The majority of data came from SCI or SCORE-supported MDA surveys. SCI provided huge unpublished data, and we made sure to avoid duplication of data that has been published from the same data. We did the same with the SCORE data. 
medRxiv preprint doi: https://doi.org/10.1101/2021.05.10.21256643; this version posted May 15, 2021. The copyright holder for this preprint (which was not certified by peer review) is the author/funder, who has granted medRxiv a license to display the preprint in perpetuity.

It is made available under a CC-BY-NC-ND 4.0 International license .

Table 1 Characteristics of the studies included in the meta-regression of schistosomiasis MDA

\begin{tabular}{|c|c|c|c|c|c|c|c|}
\hline & Study ID & Country & $\begin{array}{l}\text { Schisto } \\
\text { species }\end{array}$ & Treatment & Population & Diagnosis & $\begin{array}{l}\text { Follow-up } \\
\text { (months) }\end{array}$ \\
\hline 1 & Abudho et al., 2018 & Kenya & $\mathrm{Sm}$ & $\mathrm{PZQ}+\mathrm{ALB}$ & SAC & KK & 48 \\
\hline 2 & Assaré et al., 2016 & Cote d'Ivoire & $\mathrm{Sm}$ & PZQ & SAC & KK & 12 \\
\hline 3 & Bah et al. 2019 & Cote d'Ivoire & $\mathrm{Sm}+\mathrm{Sh}$ & PZQ & SAC & $\mathrm{KK}, \mathrm{UF}$ & 36 \\
\hline 4 & Brinkmann et al., 1988 & Mali & $\mathrm{Sm}+\mathrm{Sh}$ & PZQ & SAC & $\mathrm{KK}, \mathrm{UF}$ & 36 \\
\hline 5 & Bronzan et al., 2015 & Togo & $\mathrm{Sm}+\mathrm{Sh}$ & PZQ+ALB & SAC & KK, UF & 72 \\
\hline 6 & Hamidou et al., 2018 & Niger & Sh & PZQ & SAC & UF & 60 \\
\hline 7 & Hodges et al., 2012 & Sierra Leone & $\mathrm{Sm}$ & PZQ+ALB & SAC & KK & 6 \\
\hline 8 & Karanja et al., 2017 & Kenya & $\mathrm{Sm}$ & PZQ & SAC & KK & 60 \\
\hline 9 & Knopp et al., 2019 & Tanzania & Sh & PZQ & SAC & UF & 72 \\
\hline 10 & Lee et al., 2015 & Sudan & $\mathrm{Sm}+\mathrm{Sh}$ & PZQ & SAC & $\mathrm{KK}, \mathrm{UF}$ & $6-9$ \\
\hline 11 & Moussa et al., 2016 & Senegal & $\mathrm{Sm}+\mathrm{Sh}$ & PZQ & SAC & $\mathrm{KK}, \mathrm{UF}$ & 6 \\
\hline 12 & Mwandawiro et al., 2019 & Kenya & $\mathrm{Sm}+\mathrm{Sh}$ & PZQ & SAC & KK, UF & 60 \\
\hline 13 & Mwinzi et al., 2012 & Kenya & $\mathrm{Sm}$ & PZQ+ALB & SAC & KK & 6 \\
\hline 14 & Njenga et al., 2014 & Kenya & Sh & $\mathrm{PZQ}+\mathrm{ALB}$ & SAC & UF & 36 \\
\hline 15 & Olsen et al., 2018 & Tanzania & $\mathrm{Sm}$ & PZQ & SAC & KK & 60 \\
\hline 16 & Onkanga et al., 2016 & Kenya & $\mathrm{Sm}$ & PZQ & SAC + Adults & KK & 24 \\
\hline 17 & Ouedraogo et al., 2016 & Burkina-Faso & Sh & PZQ+ALB & SAC & UF & 108 \\
\hline 18 & Phillips et al., 2016 & Mozambique & Sh & PZQ & SAC & UF & 48 \\
\hline 19 & SCI-supported MDA 1 & Burkina Faso & $\mathrm{Sm}+\mathrm{Sh}$ & PZQ & $\mathrm{SAC}$ & $\mathrm{KK}, \mathrm{UF}$ & 48 \\
\hline 20 & SCI-supported MDA 2 & Burundi & $\mathrm{Sm}$ & PZQ & SAC + Adults & KK & 24 \\
\hline 21 & SCI-supported MDA 3 & Ethiopia & $\mathrm{Sm}+\mathrm{Sh}$ & PZQ & SAC & $\mathrm{KK}, \mathrm{UF}$ & 72 \\
\hline 22 & SCI-supported MDA 4 & Liberia & $\mathrm{Sm}+\mathrm{Sh}$ & PZQ & SAC & $\mathrm{KK}, \mathrm{UF}$ & 72 \\
\hline 23 & SCI-supported MDA 5 & Malawi & $\mathrm{Sm}+\mathrm{Sh}$ & PZQ & $\mathrm{SAC}$ & $\mathrm{KK}, \mathrm{UF}$ & 48 \\
\hline 24 & SCI-supported MDA 6 & Mali & $\mathrm{Sm}+\mathrm{Sh}$ & PZQ & SAC & KK, UF & 48 \\
\hline 25 & SCI-supported MDA 7 & Niger & $\mathrm{Sm}+\mathrm{Sh}$ & PZQ & $\mathrm{SAC}+$ Adults & KK, UF & 48 \\
\hline 26 & SCI-supported MDA 8 & Rwanda & $\mathrm{Sm}$ & PZQ & SAC + Adults & KK & 48 \\
\hline 27 & SCI-supported MDA 9 & Tanzania & $\mathrm{Sm}+\mathrm{Sh}$ & PZQ & SAC + Adults & KK, UF & $48-60$ \\
\hline 28 & SCI-supported MDA 10 & Uganda & $\mathrm{Sm}$ & PZQ & SAC + Adults & $\mathrm{KK}, \mathrm{CCA}$ & 48 \\
\hline 29 & Zhang et al., 2007 & Uganda & $\mathrm{Sm}$ & PZQ+ALB & $\mathrm{SAC}$ & KK & 48 \\
\hline 30 & Secor et al., 2020 & Kenya & $\mathrm{Sm}$ & PZQ & SAC & $\mathrm{KK}$ & 48 \\
\hline 31 & Senghor et al., 2016 & Senegal & Sh & PZQ & SAC & UF & 60 \\
\hline 32 & Sesay et al., 2014 & Sierra Leone & $\mathrm{Sm}$ & PZQ & SAC & KK & 48 \\
\hline 33 & Shen et al., 2019 & Kenya+Tanzania & $\mathrm{Sm}$ & PZQ & SAC & KK & 36 \\
\hline 34 & Sircar et al., 2018 & Kenya & $\mathrm{Sm}$ & $\mathrm{PZQ}+\mathrm{ALB}$ & SAC & KK & 60 \\
\hline
\end{tabular}

$\mathrm{PZQ}=$ Praziquantel; $\mathrm{ALB}=$ Albendazole; $\mathrm{SAC}=$ School Age Children; $\mathrm{Sm}=$ S. mansoni $; \mathrm{Sh}=$ S. haematobium $; \mathrm{KK}$ $=$ Kato-Katz; UF = Urine filtration, $\mathrm{CCA}=$ Circulating cathodic Antigen. The SCI-supported MDA data came from huge country surveys involving hundreds of villages in 10 Sub-Saharan African countries (Burkina Faso, Burundi, Ethiopia, Liberia, Malawi, Mali, Niger, Rwanda, Tanzania and Uganda). The SCI data were obtained from unpublished records. 
medRxiv preprint doi: https://doi.org/10.1101/2021.05.10.21256643; this version posted May 15, 2021. The copyright holder for this preprint (which was not certified by peer review) is the author/funder, who has granted medRxiv a license to display the preprint in perpetuity. It is made available under a CC-BY-NC-ND 4.0 International license .

\section{Prevalence versus intensity of infection}

We estimated the relationship between prevalence and intensity of infection in both $S$. mansoni and $S$. haematobium across different endemicities that showed an inverse quadratic relationship with $S$. mansoni showing slightly steeper curve than S. haematobium (Fig. 2). The graphs appear not (fully) in support of the established assumption that prevalence is directly proportional to intensity as a lot of endemic settings with high prevalence do not necessarily have proportionately high intensity (Fig. $2 \mathrm{~A}$ and B).

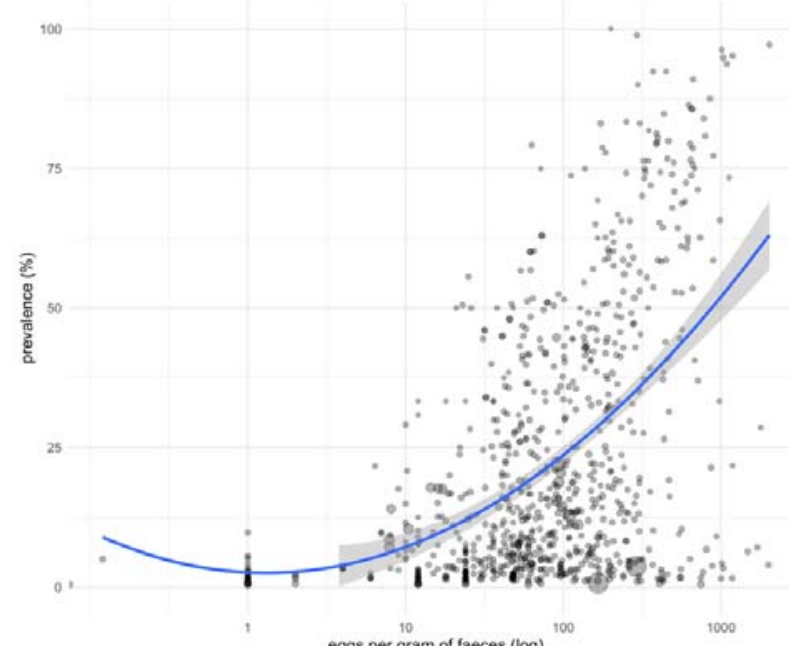

A) S. mansoni

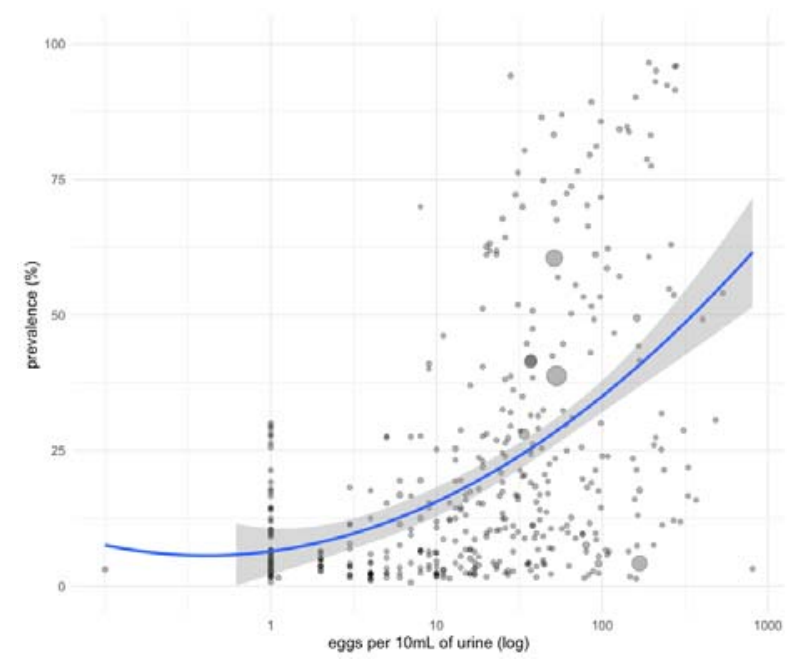

B) S. haematobium

Fig. 2 - Relationship between prevalence (as proportion) and infection intensity of infection expressed as EPG (eggs per gram of faeces) for $S$. mansoni (A) or eggs per $10 \mathrm{~mL}$ of urine for $S$. haematobium (B). The data points (black circles) came from 28 large studies involving hundreds of villages and millions of inhabitants for S. mansoni and 22 studies of hundreds of villages and thousands of inhabitants treated for S. haematobium. Given that egg output does not follow a normal distribution, EPG and eggs/10mL values (x-axis) have been reported on a log scale. A quadratic polynomial regression was fitted to depict the relationship between prevalence and intensity of infection, with their $95 \%$ CIs (grey area). The size of the circles is proportional to the size of the population.

\section{Meta-analysis of the effect of MDA over time}

We illustrate first the meta-analysis of treatment effect in school-aged children (SAC) between after baseline and successive follow-up times for S. haematobium infection at 12, 24, 36 and 48 months after annual school-based MDAs (Fig. 3). Eight studies (Phillips et al. 2016; SCI Burkina-Faso; SCI Ethiopia; SCI Liberia; SCI Malawi; SCI Mali; SCI Niger and SCI Tanzania) investigated SAC annual MDA, and the results showed a statistically significant reduction in the prevalence of infection at 12 months (RR 0.38 , 95\% CI 0.28 to $0.52 ; 8$ studies, 37,868 school children, $I^{2}=99 \%$ ); at 24 months (RR $0.30 ; 95 \%$ CI 0.30 to $0.52 ; 7$ studies; 37107 school children, $I^{2}=98 \%$ ); at 36 months (RR $0.39,95 \%$ CI 0.21 to $0.71 ; 5$ studies, 28,146 school children, $I^{2}=99 \%$ ) 
medRxiv preprint doi: https://doi.org/10.1101/2021.05.10.21256643; this version posted May 15, 2021. The copyright holder for this preprint (which was not certified by peer review) is the author/funder, who has granted medRxiv a license to display the preprint in perpetuity. It is made available under a CC-BY-NC-ND 4.0 International license .

and at 48 months although this is not statistically significant compared with baseline (RR 0.38 , $95 \%$ CI 0.14 to $1.07 ; 2$ studies; 10,954 school children, $I^{2}=98 \%$ ).

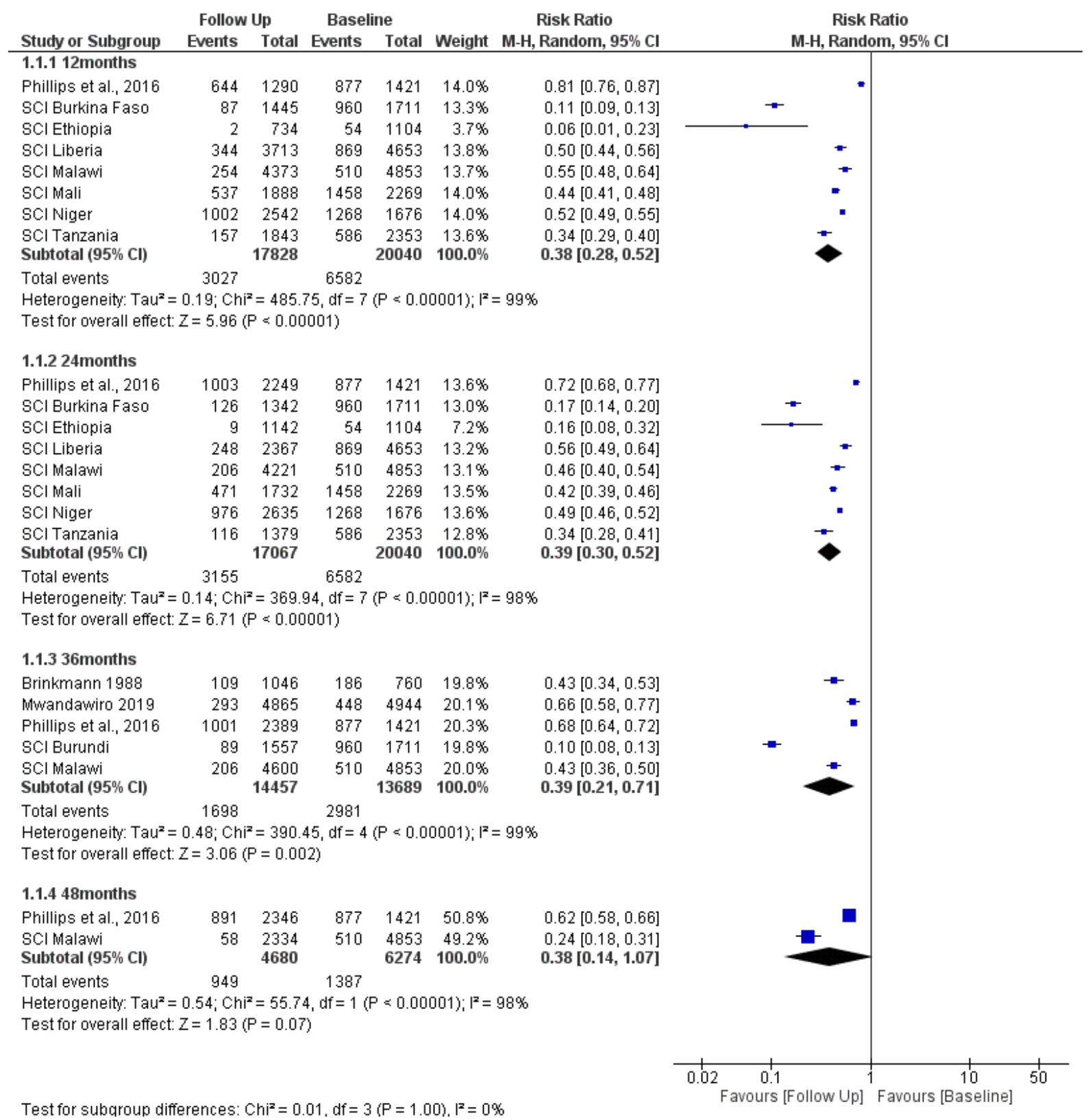

Fig. 3 - Forest plot of effectiveness of a single oral dose of $40 \mathrm{mg} / \mathrm{kg}$ in SAC for S. haematobium. The vertical line at 1 denotes the point of no difference between follow up prevalence and that of baseline so that if the $95 \%$ CI includes the value 1, it means there is no statistically significant difference between prevalence at follow up and prevalence at baseline. Each study has a square denoting the 'effect estimate' for that particular study with a horizontal line in the middle of the square that denotes the $95 \%$ CI. Each effect size with its CI is presented under 'Risk Ratio'. The size of the square denotes the contribution of the study in the pooled analysis which is quantified by the weight. The narrower the horizontal line (CI), the large the study and the higher our confidence in the estimate. The diamond denotes the pooled (overall) effect estimate. 
medRxiv preprint doi: https://doi.org/10.1101/2021.05.10.21256643; this version posted May 15, 2021. The copyright holder for this preprint (which was not certified by peer review) is the author/funder, who has granted medRxiv a license to display the preprint in perpetuity. It is made available under a CC-BY-NC-ND 4.0 International license .

We assessed the effect of annual MDA in school children (SAC) in a meta-analysis that compared prevalence at baseline with prevalence of $S$. mansoni at follow-up times 12, 24, 36 and 48 months (Fig. 4).

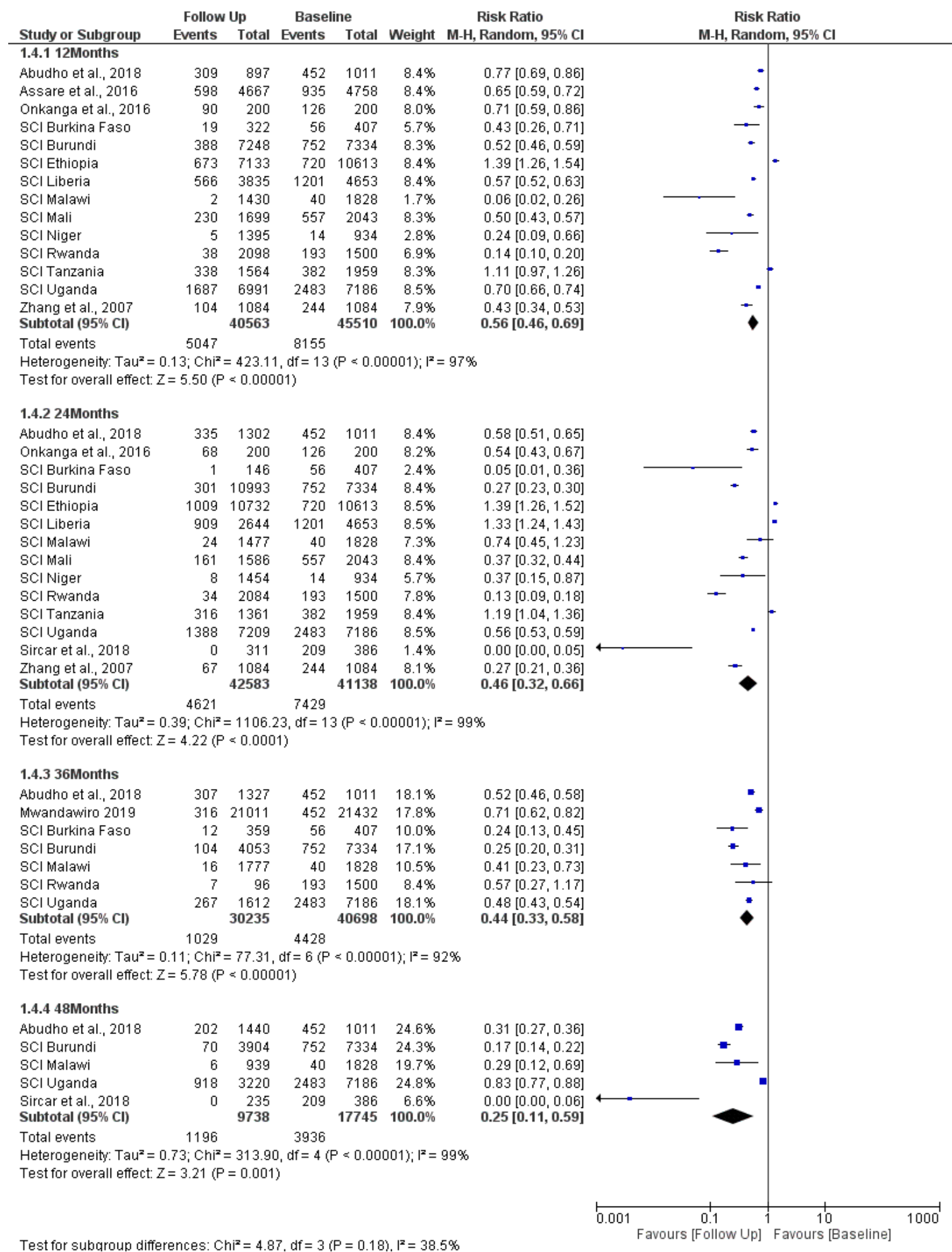

Fig. 4 Forest plot of effectiveness of single oral dose of $40 \mathrm{mg} / \mathrm{kg}$ in SAC for S. mansoni (see Fig. 3 for further explanation of the Fig.). 
medRxiv preprint doi: https://doi.org/10.1101/2021.05.10.21256643; this version posted May 15, 2021. The copyright holder for this preprint (which was not certified by peer review) is the author/funder, who has granted medRxiv a license to display the preprint in perpetuity. It is made available under a CC-BY-NC-ND 4.0 International license .

Fourteen studies (Abudho et al. 2016; Assare et al. 2016; Onkanga et al. 2016; SCI Burkina Faso; SCI Burundi; SCI Ethiopia; SCI Liberia; SCI Malawi; SCI Mali; SCI Niger; SCI Rwanda; SCI Tanzania; SCI Uganda and Zhang et al. 2007) investigated SAC annual MDA through schoolbased strategy, and the results show a reduction in prevalence with single-dose PZQ at 12 months (RR $0.56,95 \%$ CI 0.46 to $0.69 ; 14$ studies, 86,073 school children, $I^{2}=97 \%$ ); at 24 months (RR $0.46 ; 95 \%$ CI 0.32 to 0.66 ; 14 studies; 83,721 school children, $I^{2}=99 \%$ ); at 36 months (RR 0.44 , $95 \%$ CI 0.33 to $0.58 ; 7$ studies, 70933 school children, $I^{2}=92 \%$ ) and at 48 months (RR $0.25,95 \%$ CI 0.11 to $0.59 ; 5$ studies; 27,483 school children, $I^{2}=19 \%$ ).

Meta-analysis of treatment effect of MDA in adults with $S$. mansoni who received PZQ during School-based treatment by comparing prevalence at baseline and successive follow-up times at 12, 24, 36 and 48 months (Fig. 5).

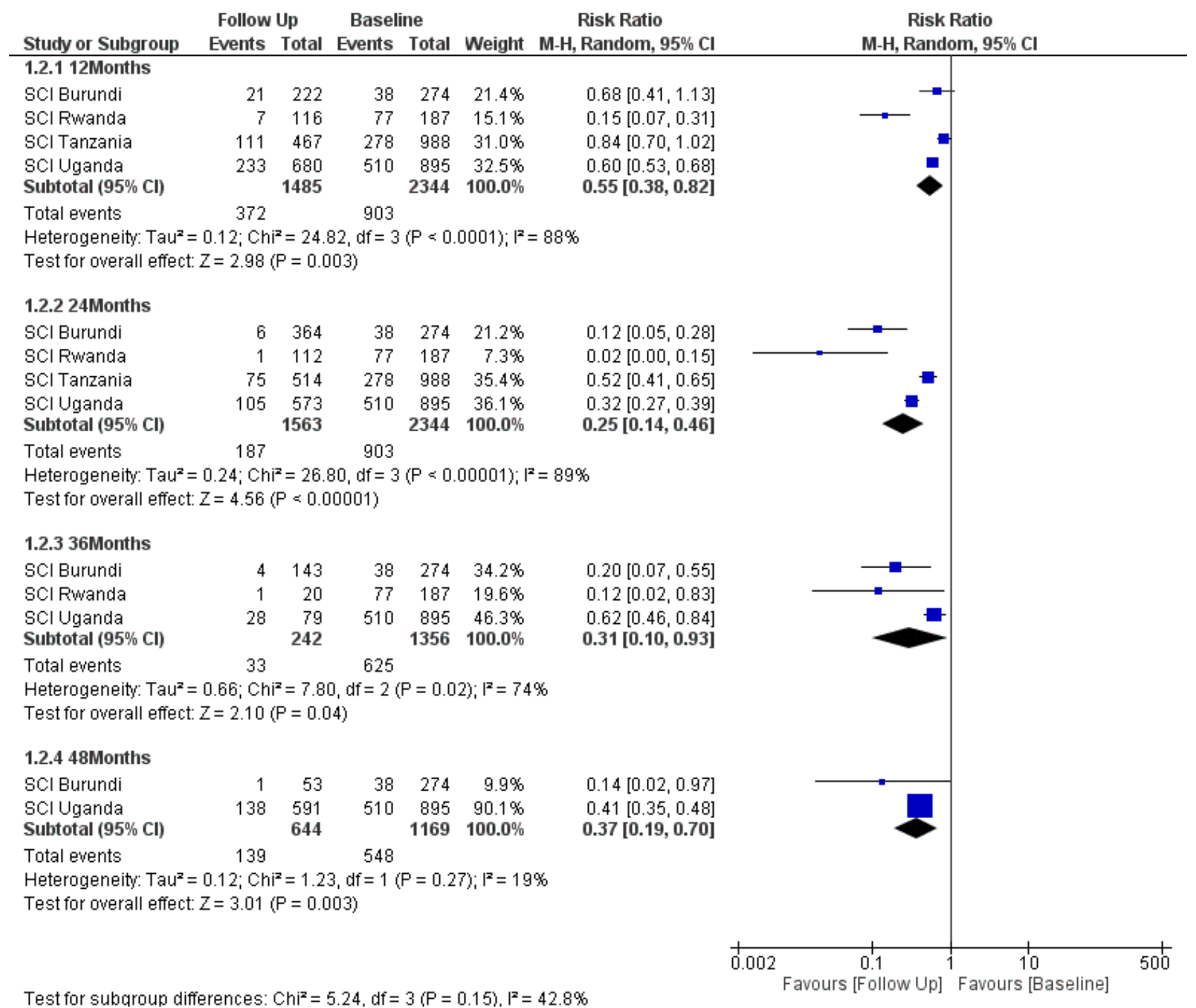

Fig. 5 Forest plot of effectiveness of single oral dose of $40 \mathrm{mg} / \mathrm{kg}$ in adults with $\mathrm{S}$. mansoni through school-based treatment MDA (see Fig. 3 for further explanation of the figure). 
medRxiv preprint doi: https://doi.org/10.1101/2021.05.10.21256643; this version posted May 15, 2021. The copyright holder for this preprint (which was not certified by peer review) is the author/funder, who has granted medRxiv a license to display the preprint in perpetuity. It is made available under a CC-BY-NC-ND 4.0 International license .

Four studies (SCI Burundi; SCI Rwanda; SCI Tanzania and SCI Uganda) investigated SAC annual MDA (Fig. 5). The results demonstrate a similar pattern as S. haematobium with MDA showing significant reductions in prevalence at 12 months (RR $0.55,95 \%$ CI 0.38 to $0.46 ; 4$ studies, 3,829 school children, $I^{2}=88 \%$ ); at 24 months (RR 0.25; 95\% CI 0.14 to 0.46 ; 4 studies; 3907 school children, $I^{2}=89 \%$ ); at 36 months (RR 0.31, 95\% CI 0.10 to 0.93 ; 3 studies, 1598 school children, $I^{2}=74 \%$ ) and at 48 months (RR $0.37,95 \%$ CI 0.19 to $0.70 ; 2$ studies; 1,813 school children, $I^{2}=19 \%$ ).

The meta-analysis of the effect of MDA in adults that compared baseline and follow-up prevalence of infection after 12, 24, 36 and 48 months of annual Community-Wide Treatment (cwt) has been presented (Fig. 3). Two studies investigated adult cwt MDA and the results showed reduction in the prevalence of infection at 12 months (RR $0.77,95 \%$ CI 0.68 to $0.88 ; 2$ studies, 1,640 school children, moderate heterogeneity $I^{2}=52 \%$ ); at 24 months (RR $0.63 ; 95 \%$ CI 0.41 to 0.99 ; 3 studies; 2,472 school children, very high heterogeneity $I^{2}=94 \%$ ); at 36 months (RR $0.40,95 \%$ CI 0.30 to $0.54 ; 2$ studies, 4,628 school children, $\left.I^{2}=85 \%\right)$ ) and at 48 months (RR $0.37,95 \%$ CI 0.19 to $0.70 ; 2$ studies; 1,813 school children, low heterogeneity $\left.I^{2}=19 \%\right)$ ).

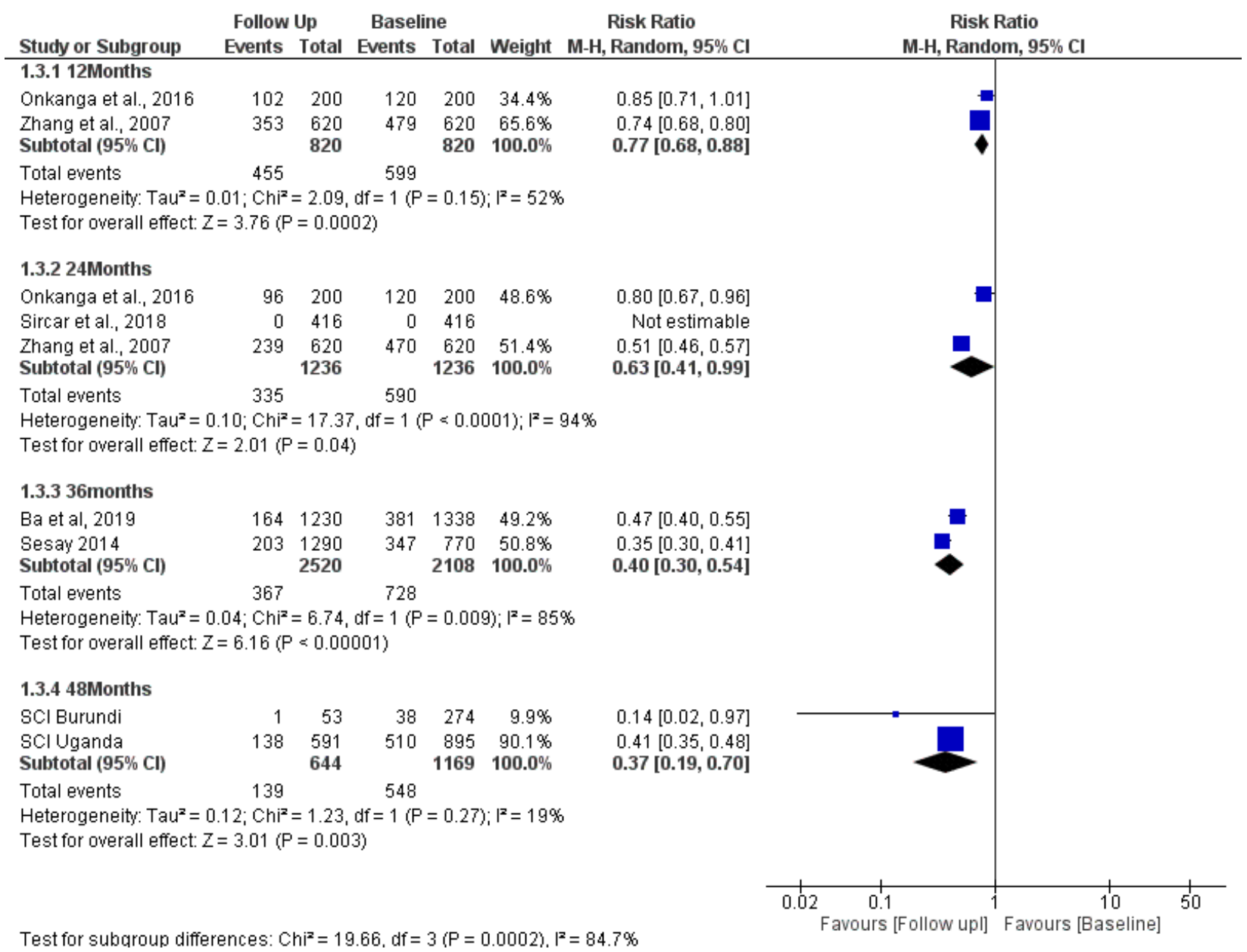


medRxiv preprint doi: https://doi.org/10.1101/2021.05.10.21256643; this version posted May 15, 2021. The copyright holder for this preprint (which was not certified by peer review) is the author/funder, who has granted medRxiv a license to display the preprint in perpetuity.

It is made available under a CC-BY-NC-ND 4.0 International license .

Fig. 5 Forest plot of effect of single oral $40 \mathrm{mg} / \mathrm{kg}$ dose in adults with $S$. mansoni treated through cwt MDA campaign (see Fig. 3 for further explanation of the figure).

\section{Longitudinal meta-analysis}

Praziquantel showed to be effective in reducing the prevalence of $S$. mansoni (PR=0.83, 95\% CI $=0.82$ to 0.83$)$ and $S$. haematobium $(\mathrm{PR}=0.76,95 \% \mathrm{CI}=0.75$ to 0.76$)$, translating into a $17 \%$ annual reduction for S. mansoni and $24 \%$ annual reduction for S. haematobium in PC/MDA programmes (as reported in Table 2 and Fig. 6). There is a sharp drop in the prevalence rate after MDA but the decrease becomes less prominent with the curves appearing to be leveling off over time. This may have important implications for control as it suggests that prevalence can drop after MDA but at some point, it becomes difficult to reduce prevalence further by repeated MDA.

Table 2 - Meta-regression results in terms of Prevalence Ratios (95\% CI) per year of treatment*

\begin{tabular}{lccc}
\hline & Studies & PR $(95 \%$ CI $)$ & p-value \\
S. mansoni & 28 & $0.827(0.823$ to 0.832$)$ & $<0.001$ \\
S. haematobium & 19 & $0.756(0.751$ to 0.761$)$ & $<0.001$
\end{tabular}

*Meta-analyses were performed separately for each species. Estimates are derived from GLLM for longitudinal data.

A S. mansoni

$25 \%$ -

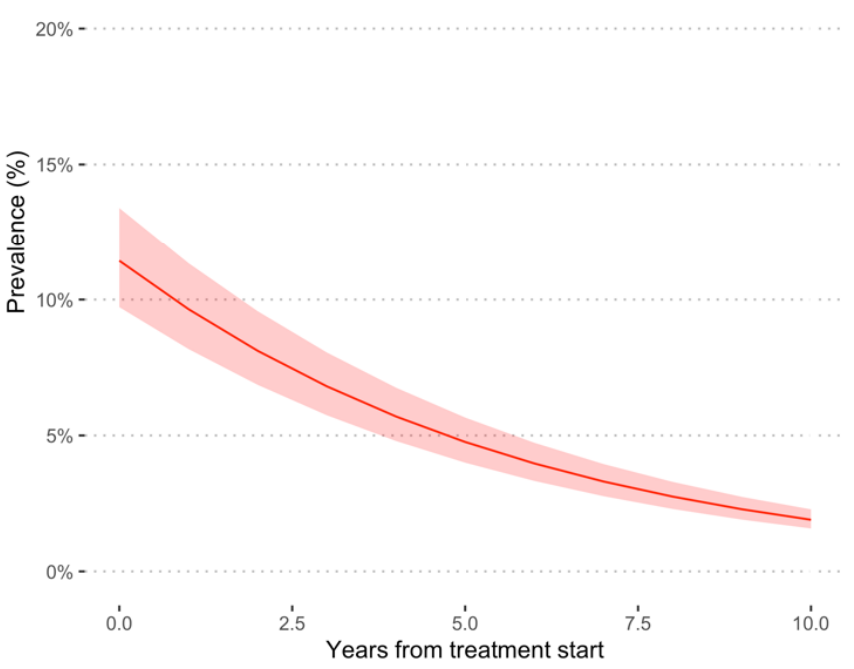

B S. haematobium

$25 \%$

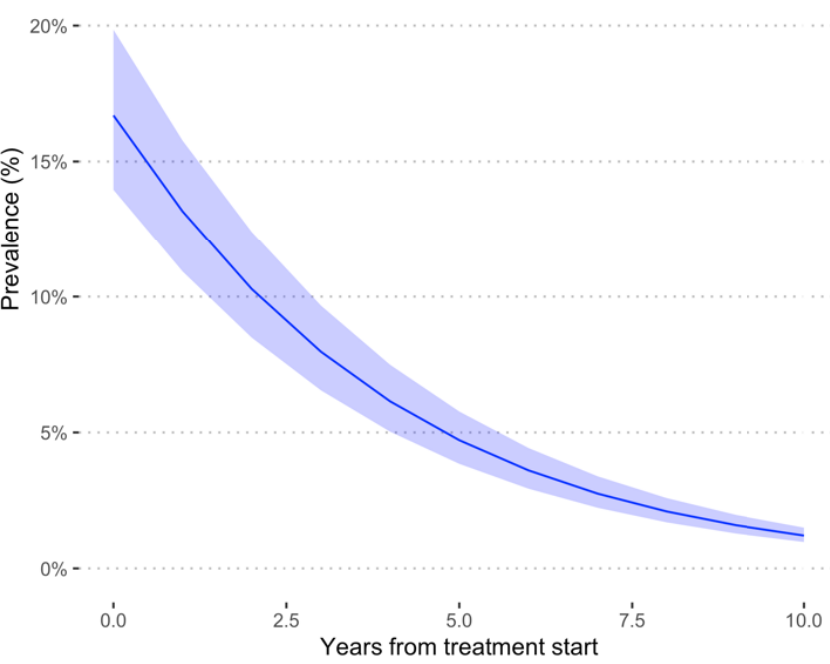

Fig. 6 Estimated prevalence at baseline and at different follow-up times during annual MDA for S. mansoni (A) and S. haematobium (B). All the studies used PZQ $40 \mathrm{mg} / \mathrm{kg}$ administered as a 
medRxiv preprint doi: https://doi.org/10.1101/2021.05.10.21256643; this version posted May 15, 2021. The copyright holder for this preprint (which was not certified by peer review) is the author/funder, who has granted medRxiv a license to display the preprint in perpetuity.

It is made available under a CC-BY-NC-ND 4.0 International license .

single oral dose alone or in combination with Albendazole (400 mg) in MDA campaigns in endemic countries in Sub-Saharan Africa.

We conducted further analysis on prevalence rates at baseline and after annual MDA for SAC and adults for $S$. mansoni and S. haematobium (Fig. 7 A, B, C, D). for both SAC and adults prevalence rates decrease, more prominently in SAC (A and C) but not so much for adults with $S$. mansoni or S. haematobium (Fig. B and D). Fig. 7B shows that after a decrease of up to 2 years, prevalence starts to increase. The same is observed for MDA for adults with S. haematobium where the drop in prevalence levels off after about two years and bounces back (Fig. 7D).

A S. mansoni - SAC

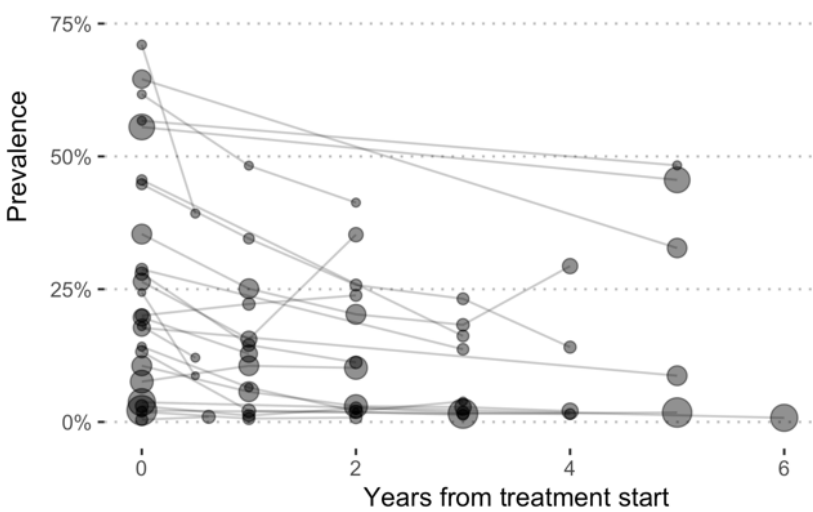

C

S. haematobium - SAC

$100 \%-$

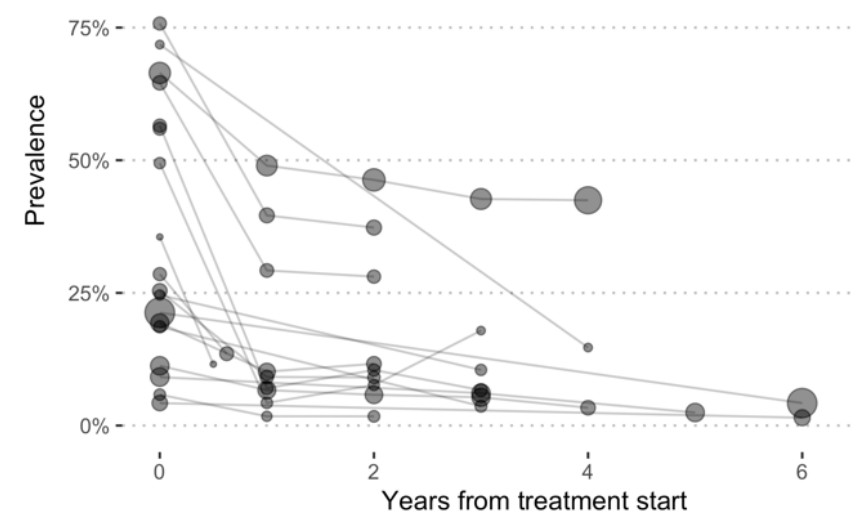

B S. mansoni - Adults

$100 \%-$

$75 \%$

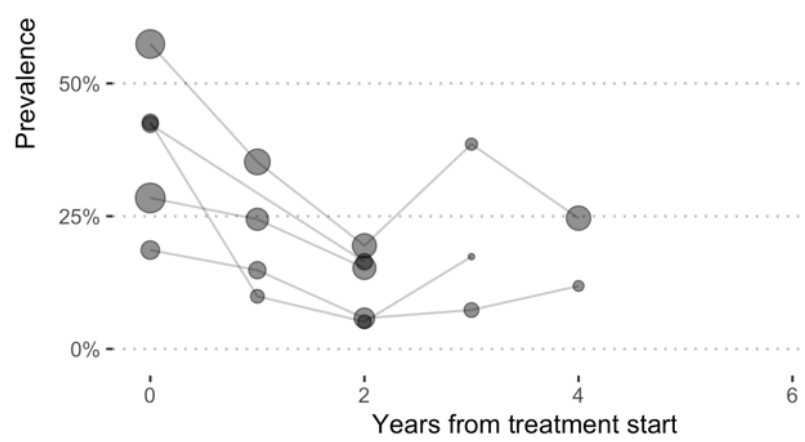

D S. haematobium - Adults

$100 \%-$

$75 \%-$

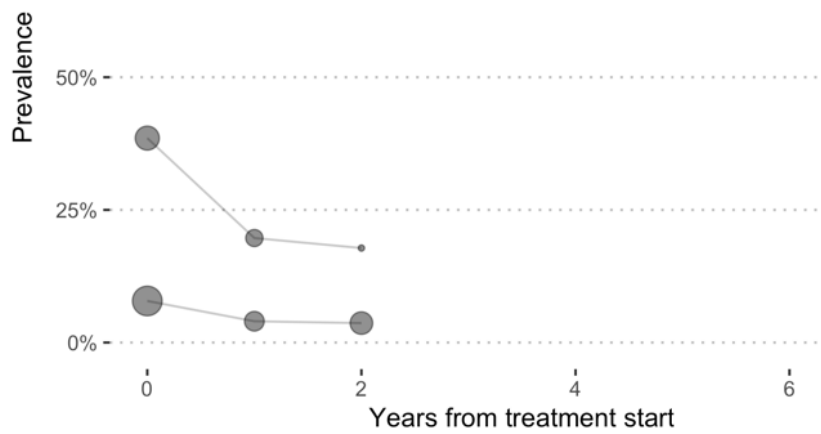

Fig. 7 Prevalence Rates over time points following MDA of adults are plotted for studies that investigated S. mansoni in SAC (A), S. mansoni in adults (B), S. haematobium SAC (C) and S. haematobium adults (D). The size of the circles is proportional to the tested population at each follow-up assessment. Follow up was up to six years. 
medRxiv preprint doi: https://doi.org/10.1101/2021.05.10.21256643; this version posted May 15, 2021. The copyright holder for this preprint (which was not certified by peer review) is the author/funder, who has granted medRxiv a license to display the preprint in perpetuity.

It is made available under a CC-BY-NC-ND 4.0 International license.

\section{Longitudinal data}

\begin{tabular}{|c|c|c|c|c|c|c|c|c|}
\hline Schisto & N_subjects & N_studies & Com_arms & Age & MDA & Threshold & PR & PR_95_CI \\
\hline S. mansoni & 9104 & 5 & 5 & SAC & $\begin{array}{l}\text { Annual } \\
\text { CWT } \\
\text { Annual }\end{array}$ & 0.05 & 0.852 & $0.852(0.833-0.87$ \\
\hline S. mansoni & 9104 & 5 & 5 & SAC & $\begin{array}{l}\text { CWT } \\
\text { Annual }\end{array}$ & 0.1 & 0.852 & $0.852(0.833-0.87$ \\
\hline S. mansoni & 9104 & 5 & 5 & SAC & $\begin{array}{l}\text { CWT } \\
\text { Annual }\end{array}$ & 0.15 & 0.852 & $0.852(0.833-0.87$ \\
\hline S. mansoni & 123045 & 20 & 181 & SAC & $\begin{array}{l}\text { SBT } \\
\text { Annual }\end{array}$ & 0.05 & 0.783 & $0.783(0.775-0.79)$ \\
\hline S. mansoni & 97943 & 19 & 141 & SAC & $\begin{array}{l}\text { SBT } \\
\text { Annual }\end{array}$ & 0.1 & 0.778 & $0.778(0.771-0.78 t$ \\
\hline S. mansoni & 84647 & 18 & 121 & SAC & $\begin{array}{l}\text { SBT } \\
\text { Annual }\end{array}$ & 0.15 & 0.769 & $0.769\left(0.762-0.77^{-}\right.$ \\
\hline S. mansoni & 5358 & 4 & 32 & Adults & $\begin{array}{l}\text { SBT } \\
\text { Annual }\end{array}$ & 0.05 & 0.665 & $0.665(0.63-0.702)$ \\
\hline S. mansoni & 5065 & 4 & 29 & Adults & $\begin{array}{l}\text { SBT } \\
\text { Annual }\end{array}$ & 0.1 & 0.661 & $0.661(0.626-0.698$ \\
\hline S. mansoni & 4879 & 4 & 26 & Adults & $\begin{array}{l}\text { SBT } \\
\text { Annual }\end{array}$ & 0.15 & 0.66 & $0.66(0.625-0.697)$ \\
\hline S. haematobium & 20646 & 4 & 4 & SAC & $\begin{array}{l}\text { CWT } \\
\text { Annual }\end{array}$ & 0.05 & 0.821 & $0.821(0.804-0.83\{$ \\
\hline S. haematobium & 20646 & 4 & 4 & SAC & $\begin{array}{l}\text { CWT } \\
\text { Annual }\end{array}$ & 0.1 & 0.821 & $0.821(0.804-0.83\{$ \\
\hline S. haematobium & 13600 & 3 & 3 & SAC & $\begin{array}{l}\text { CWT } \\
\text { Annual }\end{array}$ & 0.15 & 0.71 & $0.71(0.69-0.731)$ \\
\hline S. haematobium & 106912 & 13 & 123 & SAC & $\begin{array}{l}\text { SBT } \\
\text { Annual }\end{array}$ & 0.05 & 0.743 & $0.743(0.736-0.75$ \\
\hline S. haematobium & 99931 & 13 & 105 & SAC & $\begin{array}{l}\text { SBT } \\
\text { Annual }\end{array}$ & 0.1 & 0.743 & $0.743(0.736-0.75$ \\
\hline S. haematobium & 91555 & 13 & 91 & SAC & $\begin{array}{l}\text { SBT } \\
\text { Annual }\end{array}$ & 0.15 & 0.743 & $0.743(0.735-0.75)$ \\
\hline S. haematobium & 1722 & 2 & 6 & Adults & $\begin{array}{l}\text { SBT } \\
\text { Annual }\end{array}$ & 0.05 & 0.575 & $0.575\left(0.475-0.69^{-}\right.$ \\
\hline S. haematobium & 1722 & 2 & 6 & Adults & $\begin{array}{l}\text { SBT } \\
\text { Annual }\end{array}$ & 0.1 & 0.575 & $0.575\left(0.475-0.69^{-}\right.$ \\
\hline S. haematobium & 1284 & 2 & 5 & Adults & SBT & 0.15 & 0.569 & $0.569(0.462-0.70$ \\
\hline
\end{tabular}

Com_arms = number of communities_arms

Results for specific MDA programs have been described in Table 3 and Table 4. For adults 
medRxiv preprint doi: https://doi.org/10.1101/2021.05.10.21256643; this version posted May 15, 2021. The copyright holder for this preprint (which was not certified by peer review) is the author/funder, who has granted medRxiv a license to display the preprint in perpetuity.

It is made available under a CC-BY-NC-ND 4.0 International license .

Table 3 - Meta-regression results in terms of Prevalence Ratios (PR, 95\% CI) per year of treatment and baseline prevalence or type of treatment for S. mansoni

\begin{tabular}{lllll}
\hline Age & MDA & $\begin{array}{l}\text { Baseline } \\
\text { Prevalence }\end{array}$ & PR (95\% CI) & Studies \\
\hline Adults & Annual SBT & low & $0.936(0.716-1.222)$ & 2 \\
Adults & Annual SBT & moderate & $0.699(0.637$ to 0.768$)$ & 4 \\
Adults & Annual SBT & high & $0.659(0.615$ to 0.707$)$ & 3 \\
SAC & Annual CWT & high & $0.507(0.457$ to 0.562$)$ & 3 \\
SAC & Annual SBT & low & $0.878(0.86$ to 0.897$)$ & 12 \\
SAC & Annual SBT & moderate & $0.706(0.691$ to 0.721$)$ & 14 \\
SAC & Annual SBT & high & $0.682(0.662$ to 0.703$)$ & 9 \\
SAC & Annual SBT-CWT & high & $0.514(0.463$ to 0.57$)$ & 1 \\
SAC & Annual SBT-CWT & moderate & $0.678(0.614$ to 0.75$)$ & 1 \\
\hline
\end{tabular}

$\mathrm{SAC}=$ school age children; $\mathrm{CWT}=$ community wide treatment; $\mathrm{SBT}=$ school-based treatment; $\mathrm{MDA}=$ mass drug administration; $\mathrm{PR}=$ prevalence ratio; $\mathrm{CI}=$ confident interval. * Estimates are derived from GLLM for longitudinal data.

Table 4 - Meta-regression results in terms of Prevalence Ratios (PR, 95\% CI) per year of treatment and baseline intensity of infection or type of treatment for S. haematobium

\begin{tabular}{lllll}
\hline Age & MDA & $\begin{array}{l}\text { Baseline } \\
\text { Prevalence }\end{array}$ & PR $(\mathbf{9 5 \%}$ CI $)$ & Studies \\
\hline Adults & Annual SBT & moderate & $0.585(0.477$ to 0.719$)$ & 2 \\
All & Annual CWT & high & $0.562(0.513$ to 0.615$)$ & 1 \\
All & Annual CWT & moderate & $0.471(0.396$ to 0.561$)$ & 1 \\
SAC & Annual CWT & high & $0.828(0.811$ to 0.845$)$ & 3 \\
SAC & Annual SBT & low & $0.761(0.722$ to 0.803$)$ & 7 \\
SAC & Annual SBT & moderate & $0.721(0.712$ to 0.731$)$ & 9 \\
SAC & Annual SBT & high & $0.774(0.762$ to 0.787$)$ & 7 \\
Adults & Annual SBT & moderate & $0.585(0.477$ to 0.719$)$ & 2 \\
\hline
\end{tabular}

$\mathrm{SAC}=$ school age children; $\mathrm{cwt}=$ community wide treatment; $\mathrm{sbt}=$ school-based treatment; MDA = mass drug administration; $\mathrm{PR}=$ prevalence ratio; $\mathrm{CI}=$ confident interval. Estimates are derived from GLLM.

\section{Prevalence reduction following MDA}

Different communities within a study and repeated follow-ups were each considered as separate data points. The interdependence between observations (communities and repeated follow-ups) within the same study was accounted for by using linear mixed modelling (LMM). In the GLMM study and /or study arms were considered as random intercepts and random slopes (DansoAppiah and De Vlas 2002). Marginal estimates are then plotted along their 95\% CI. The lme4 R 
medRxiv preprint doi: https://doi.org/10.1101/2021.05.10.21256643; this version posted May 15, 2021. The copyright holder for this preprint (which was not certified by peer review) is the author/funder, who has granted medRxiv a license to display the preprint in perpetuity.

It is made available under a CC-BY-NC-ND 4.0 International license .

package was used to estimate the impact, variance and covariance of random and fixed effects. Significances of the coefficients were assessed by the Wald-test.

A S. mansoni-SAC

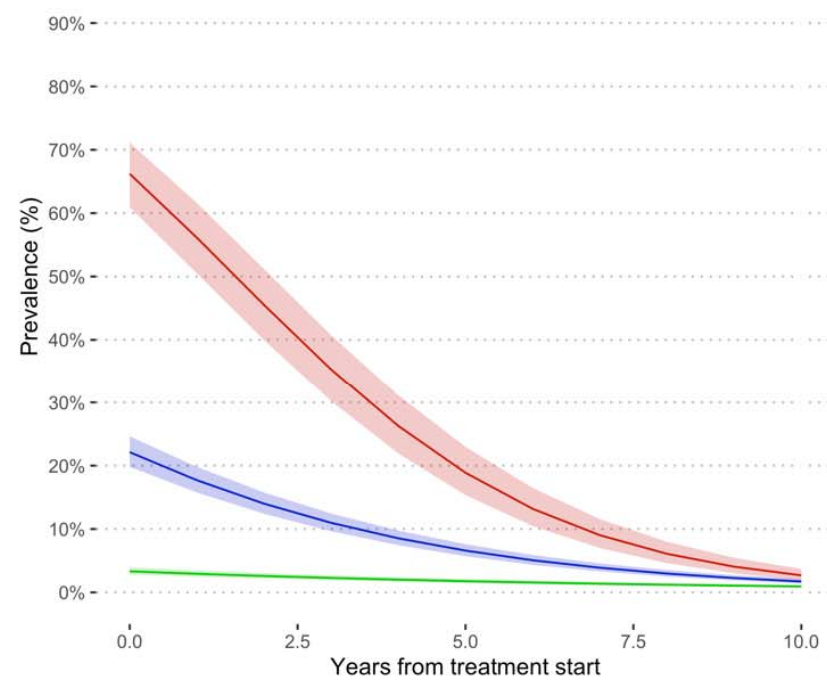

C S. haematobium - SAC

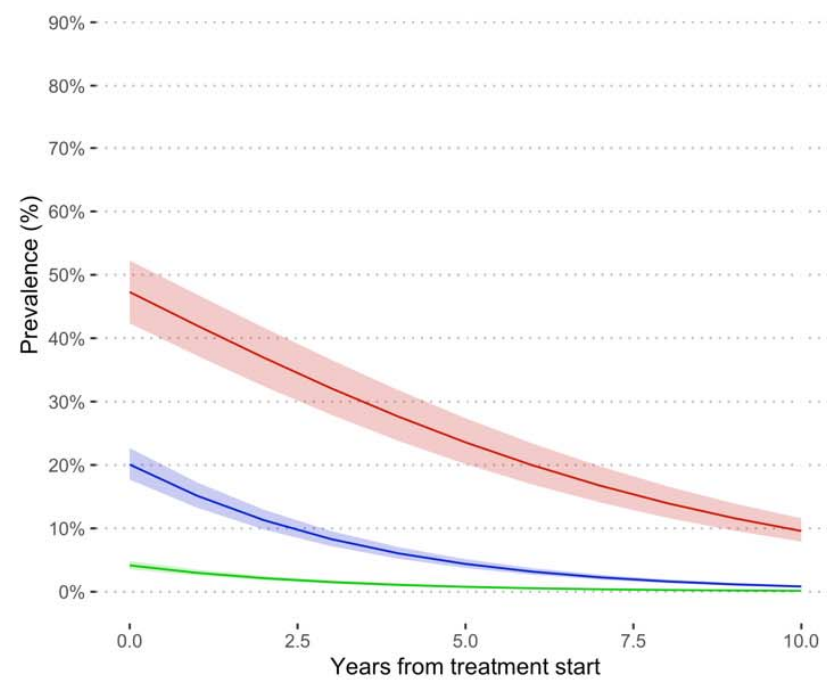

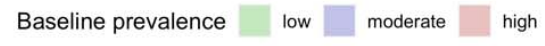

B S. mansoni - Adults

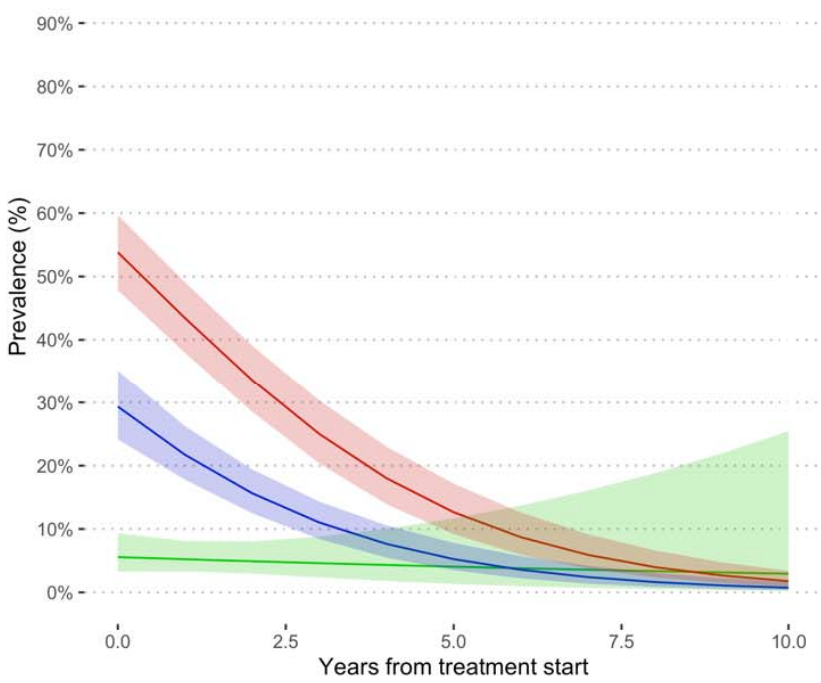

D S. haematobium - Adults

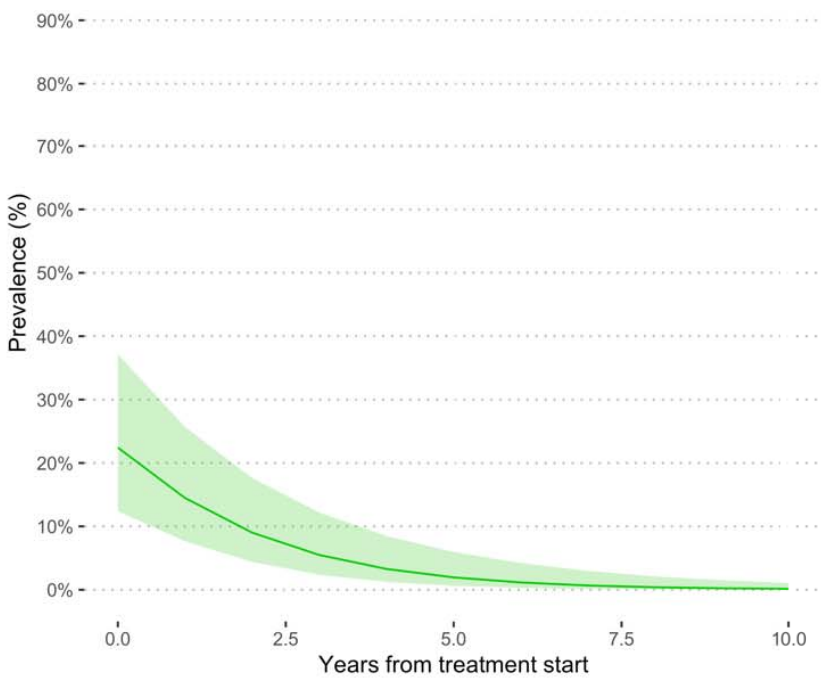

Fig. 8 Estimated prevalence at baseline and at different follow-up times during MDA for $S$. mansoni (A-B) and S. haematobium (C-D). High prevalence (pink colour) is defined as prevalence $\geq 50 \%$ by microscopy and $\geq 60 \%$ by CCA, moderate (blue colour) is prevalence $=10 \%$ but $<50 \%$ by microscopy and $\leq 15 \%$ but $<60 \%$ by CCA and low prevalence (green colour) is prevalence $<10 \%$ by and $<15 \%$ by CCA. All the studies used PZQ $40 \mathrm{mg} / \mathrm{kg}$ administered as a single oral dose alone or in combination with Albendazole (400 mg) in MDA campaigns in endemic countries in Sub-Saharan Africa. 
medRxiv preprint doi: https://doi.org/10.1101/2021.05.10.21256643; this version posted May 15, 2021. The copyright holder for this preprint (which was not certified by peer review) is the author/funder, who has granted medRxiv a license to display the preprint in perpetuity.

It is made available under a CC-BY-NC-ND 4.0 International license .

S. mansoni - SAC

Baseline prevalence $\square$ low $\square$ moderate $\square$ high

Annual CWT

Annual SBT

Annual SBT-CWT

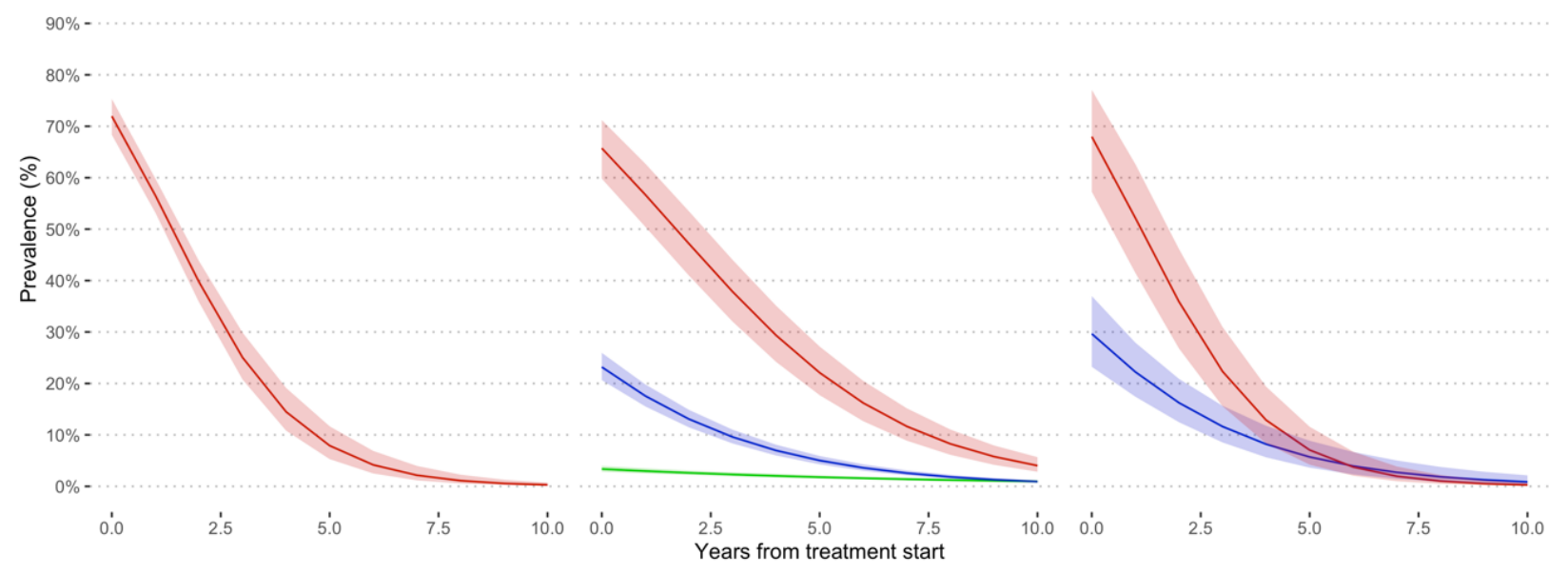

Fig. 9a Estimated prevalence at baseline and at different follow-up times during MDA involving school-age children for S. mansoni. Prevalence categories have been defined using WHO classification (WHO 2012). High prevalence is defined as prevalence $\geq 50 \%$ by microscopy and $\geq 60 \%$ by CCA, moderate is prevalence $=10 \%$ but $<50 \%$ by microscopy and $\leq 15 \%$ but $<60 \%$ by CCA and low prevalence is prevalence $<10 \%$ by and $<15 \%$ by CCA. All the studies used PZQ 40 $\mathrm{mg} / \mathrm{kg}$ administered as a single oral dose alone or in combination with Albendazole $(400 \mathrm{mg}$ ) in MDA campaigns in endemic countries in Sub-Saharan Africa. SBT means school-based treatment and CWT community-wide treatment. 
medRxiv preprint doi: https://doi.org/10.1101/2021.05.10.21256643; this version posted May 15, 2021. The copyright holder for this preprint (which was not certified by peer review) is the author/funder, who has granted medRxiv a license to display the preprint in perpetuity.

It is made available under a CC-BY-NC-ND 4.0 International license .

\section{S. mansoni - Adults}

\section{Annual SBT}

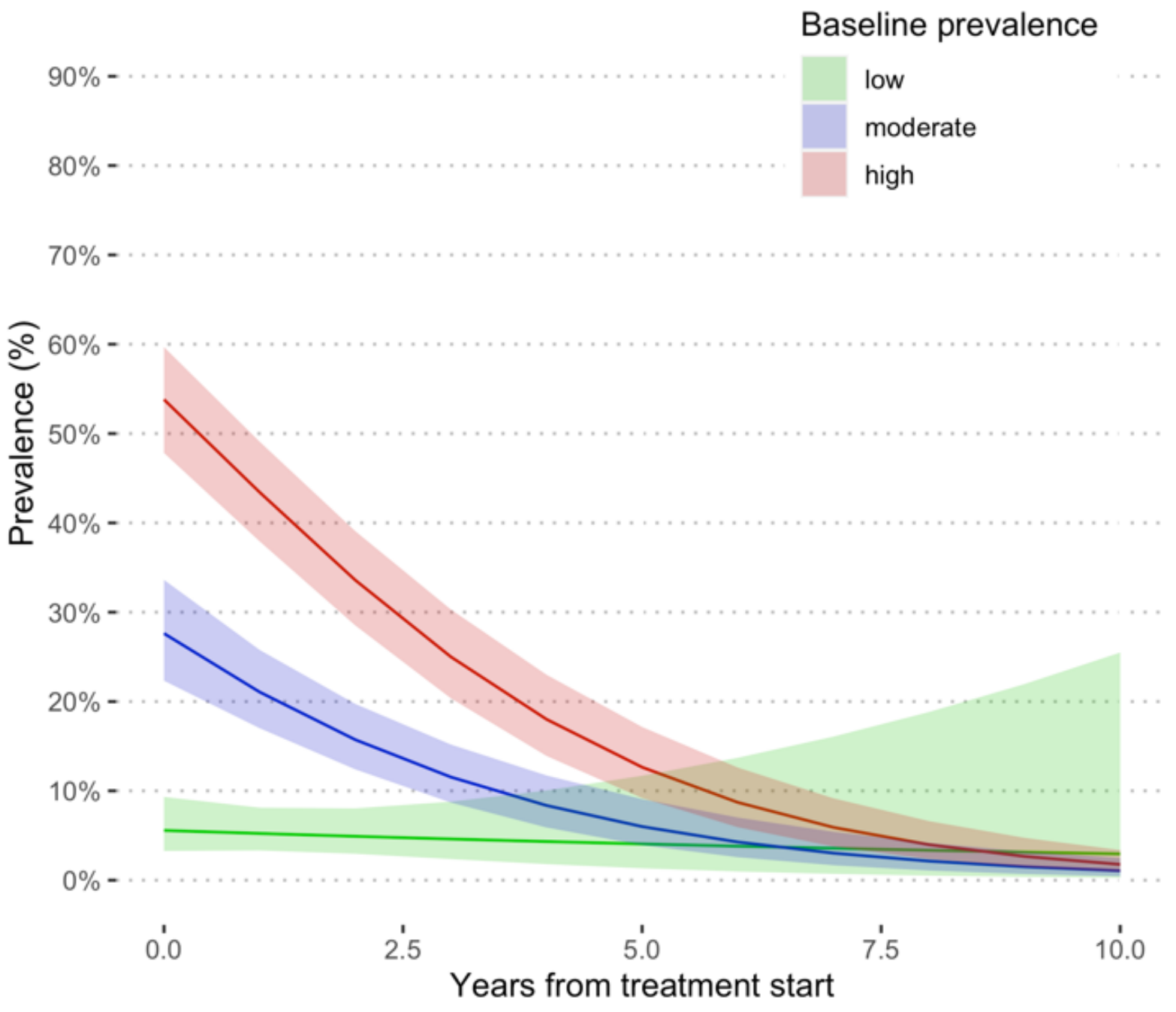

Fig. 9b Estimated prevalence at baseline and at different follow-up times during MDA involving Adults for S. mansoni. Prevalence categories have been defined using WHO classification (WHO 2012). High prevalence is defined as prevalence $\geq 50 \%$ by microscopy and $\geq 60 \%$ by CCA, moderate is prevalence $=10 \%$ but $<50 \%$ by microscopy and $\leq 15 \%$ but $<60 \%$ by CCA and low prevalence is prevalence $<10 \%$ by and $<15 \%$ by CCA. All the studies used PZQ $40 \mathrm{mg} / \mathrm{kg}$ administered as a single oral dose alone or in combination with Albendazole (400 mg) in MDA campaigns in endemic countries in Sub-Saharan Africa. SBT means school-based treatment. 
medRxiv preprint doi: https://doi.org/10.1101/2021.05.10.21256643; this version posted May 15, 2021. The copyright holder for this preprint (which was not certified by peer review) is the author/funder, who has granted medRxiv a license to display the preprint in perpetuity.

It is made available under a CC-BY-NC-ND 4.0 International license .

S. haematobium - SAC

Annual CWT

Annual SBT

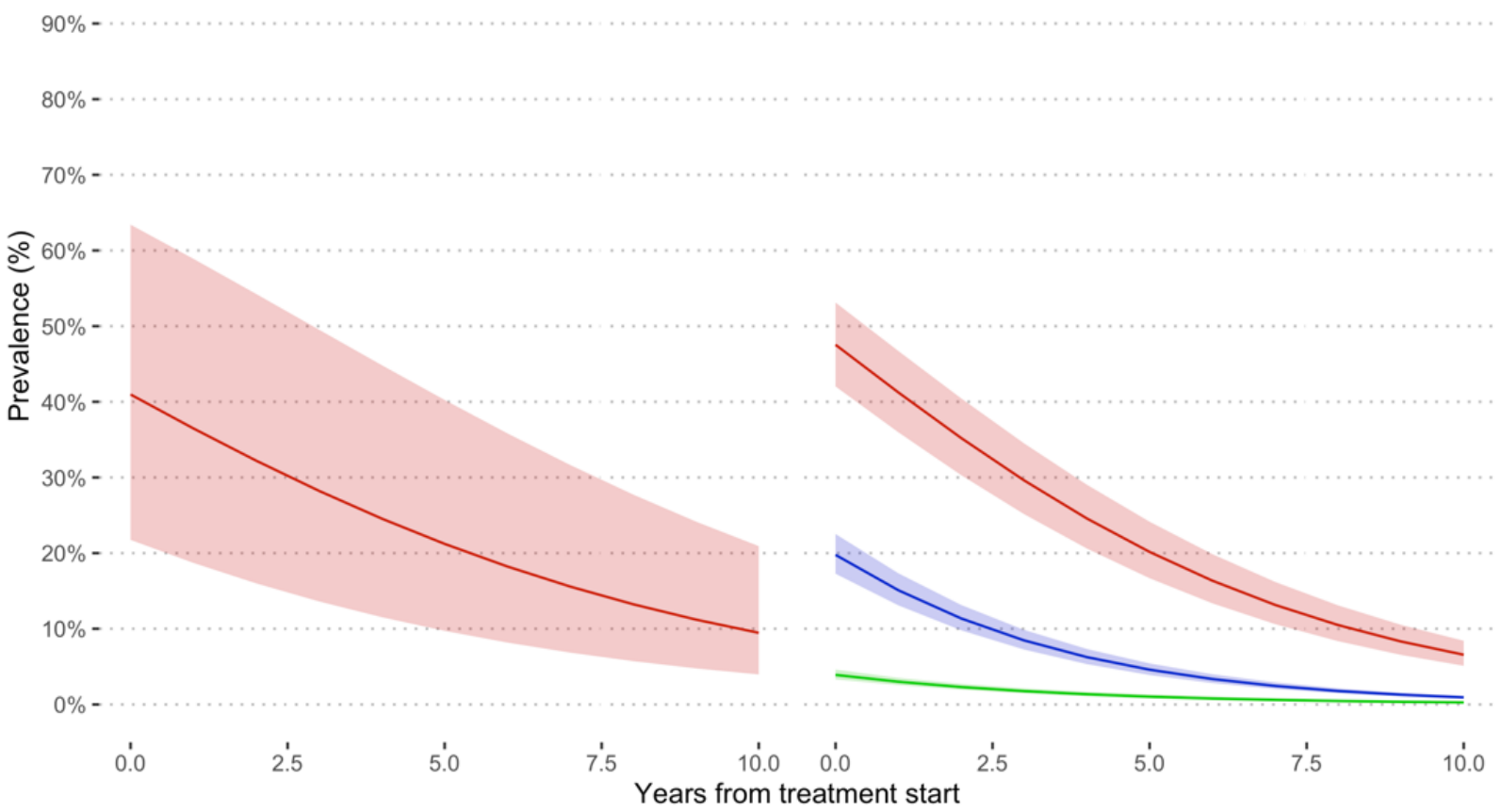

Fig. 9c Estimated prevalence at baseline and at different follow-up times during MDA involving school-age children for S. haematobium. Prevalence categories have been defined using WHO classification (WHO 2012). High prevalence is defined as prevalence $\geq 50 \%$ by microscopy and $\geq 60 \%$ by CCA, moderate is prevalence $=10 \%$ but $<50 \%$ by microscopy and $\leq 15 \%$ but $<60 \%$ by CCA and low prevalence is prevalence $<10 \%$ by and $<15 \%$ by CCA. All the studies used PZQ 40 $\mathrm{mg} / \mathrm{kg}$ administered as a single oral dose alone or in combination with Albendazole $(400 \mathrm{mg}$ ) in MDA campaigns in endemic countries in Sub-Saharan Africa. SBT means school-based treatment and CWT community-wide treatment. 
medRxiv preprint doi: https://doi.org/10.1101/2021.05.10.21256643; this version posted May 15, 2021. The copyright holder for this preprint (which was not certified by peer review) is the author/funder, who has granted medRxiv a license to display the preprint in perpetuity.

It is made available under a CC-BY-NC-ND 4.0 International license .

\section{S. haematobium - Adults}

\section{Annual SBT}

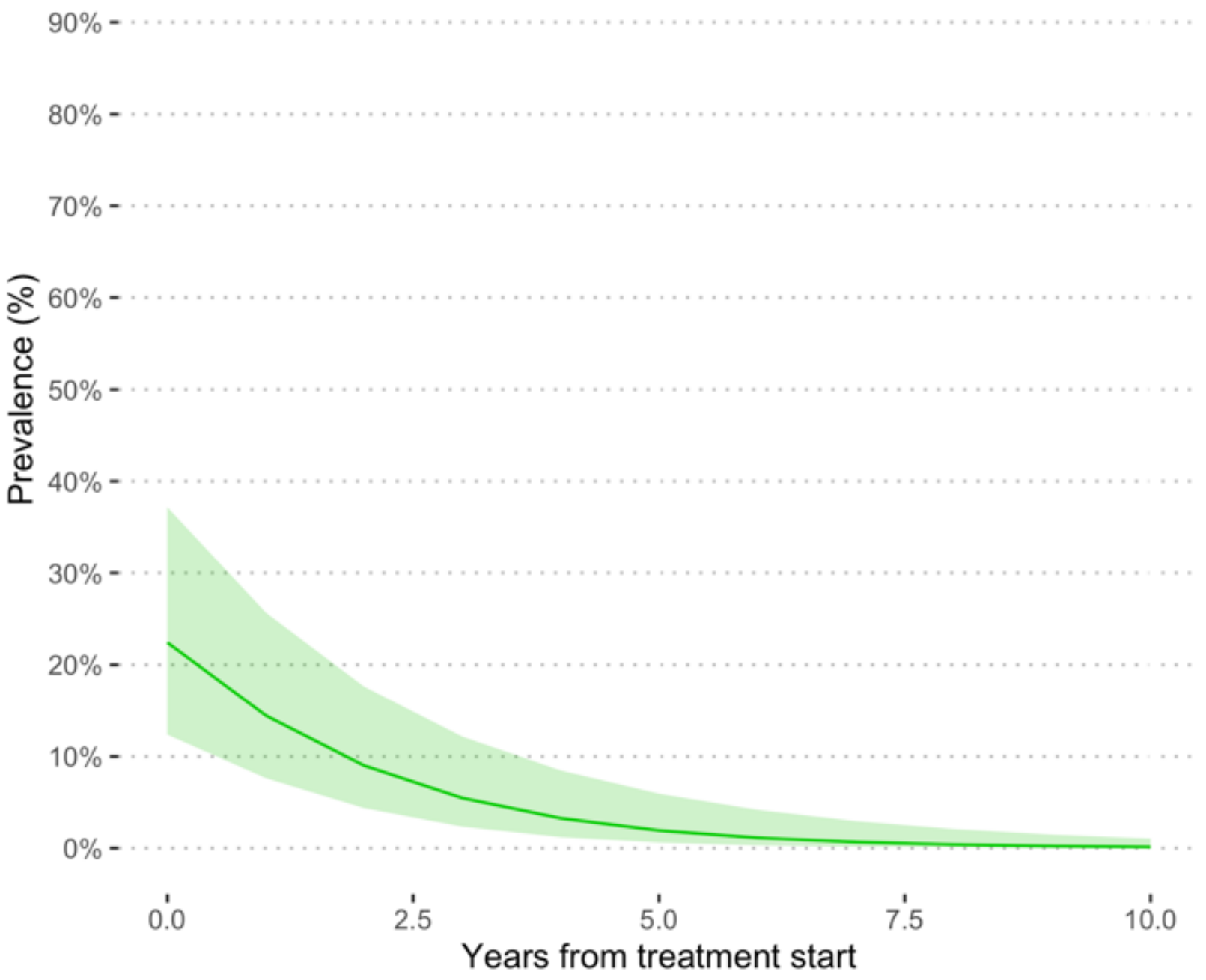

Fig. 9d Estimated prevalence at baseline and at different follow-up times during MDA involving Adults for $S$. haematobium. Prevalence categories have been defined using WHO classification (WHO 2012). High prevalence is defined as prevalence $\geq 50 \%$ by microscopy and $\geq 60 \%$ by CCA, moderate is prevalence $=10 \%$ but $<50 \%$ by microscopy and $\leq 15 \%$ but $<60 \%$ by CCA and low prevalence is prevalence $<10 \%$ by and $<15 \%$ by CCA. All the studies used PZQ $40 \mathrm{mg} / \mathrm{kg}$ administered as a single oral dose alone or in combination with Albendazole (400 $\mathrm{mg}$ ) in MDA campaigns in endemic countries in Sub-Saharan Africa. SBT means school-based treatment. 
medRxiv preprint doi: https://doi.org/10.1101/2021.05.10.21256643; this version posted May 15, 2021. The copyright holder for this preprint (which was not certified by peer review) is the author/funder, who has granted medRxiv a license to display the preprint in perpetuity.

It is made available under a CC-BY-NC-ND 4.0 International license .

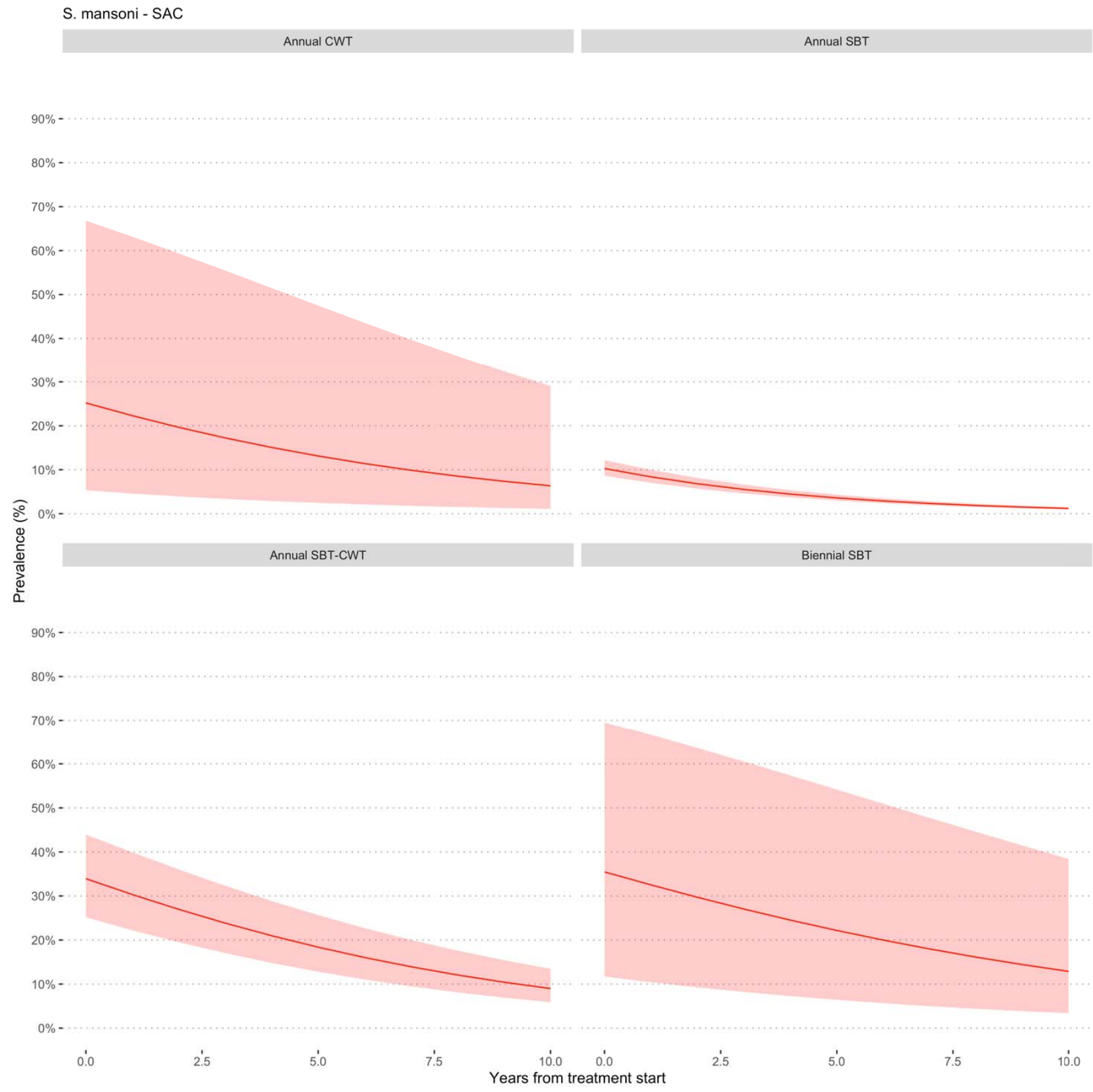

Fig. 10a Estimated prevalence at baseline and at different follow-up times during MDA involving school-age children for S. mansoni. All the studies used PZQ $40 \mathrm{mg} / \mathrm{kg}$ administered as a single oral dose alone or in combination with Albendazole (400 $\mathrm{mg}$ ) in MDA campaigns in endemic countries in Sub-Saharan Africa. 
medRxiv preprint doi: https://doi.org/10.1101/2021.05.10.21256643; this version posted May 15, 2021. The copyright holder for this preprint (which was not certified by peer review) is the author/funder, who has granted medRxiv a license to display the preprint in perpetuity.

It is made available under a CC-BY-NC-ND 4.0 International license .

\section{S. mansoni - Adults}

\section{Annual SBT}

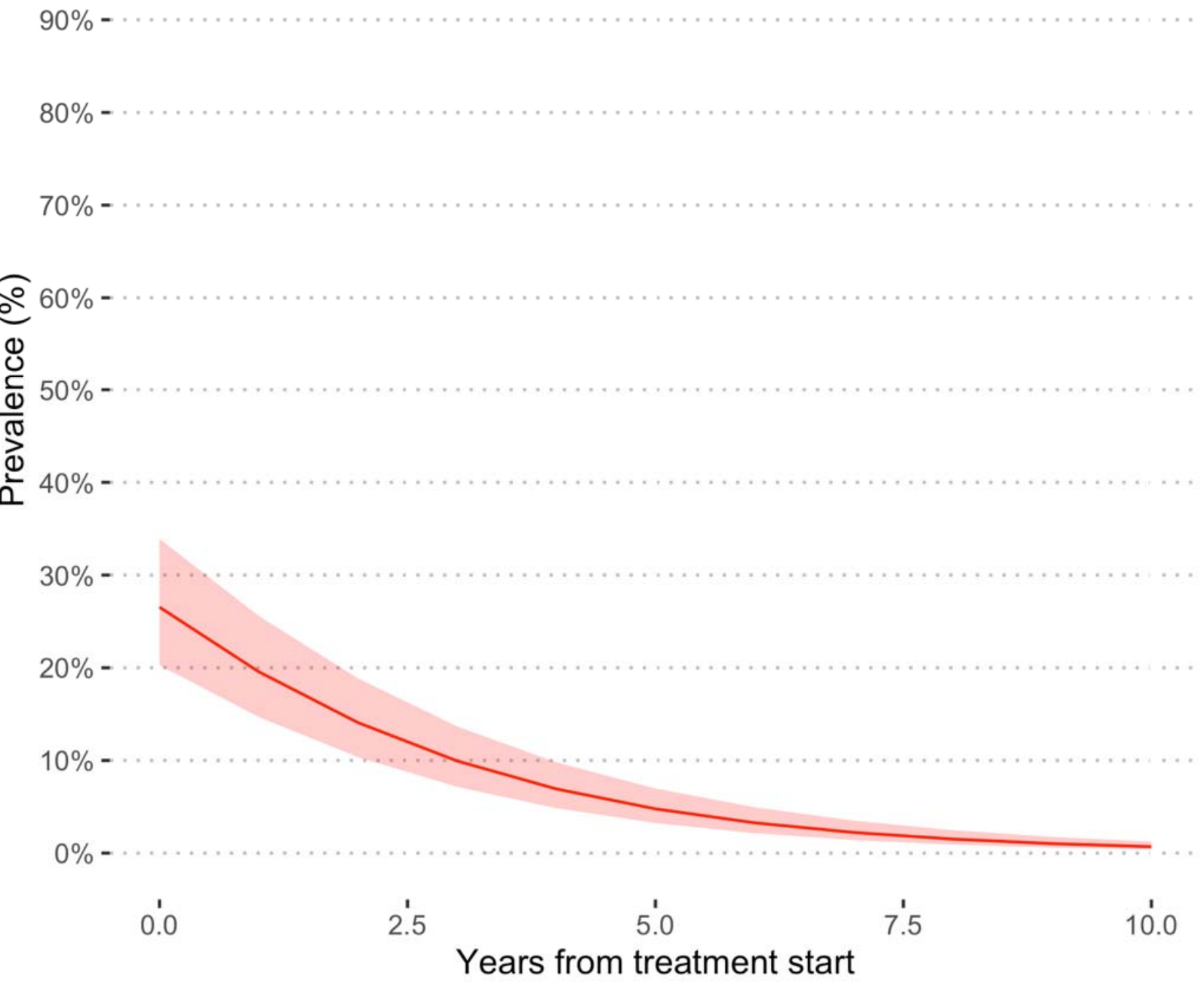

Fig. 10b Estimated prevalence at baseline and at different follow-up times during MDA involving adults for $S$. mansoni. All the studies used PZQ $40 \mathrm{mg} / \mathrm{kg}$ administered as a single oral dose alone or in combination with Albendazole (400 mg) in MDA campaigns in endemic countries in Sub-Saharan Africa. 
medRxiv preprint doi: https://doi.org/10.1101/2021.05.10.21256643; this version posted May 15, 2021. The copyright holder for this preprint (which was not certified by peer review) is the author/funder, who has granted medRxiv a license to display the preprint in perpetuity.

It is made available under a CC-BY-NC-ND 4.0 International license .

S. haematobium - SAC

Annual CWT

Annual SBT

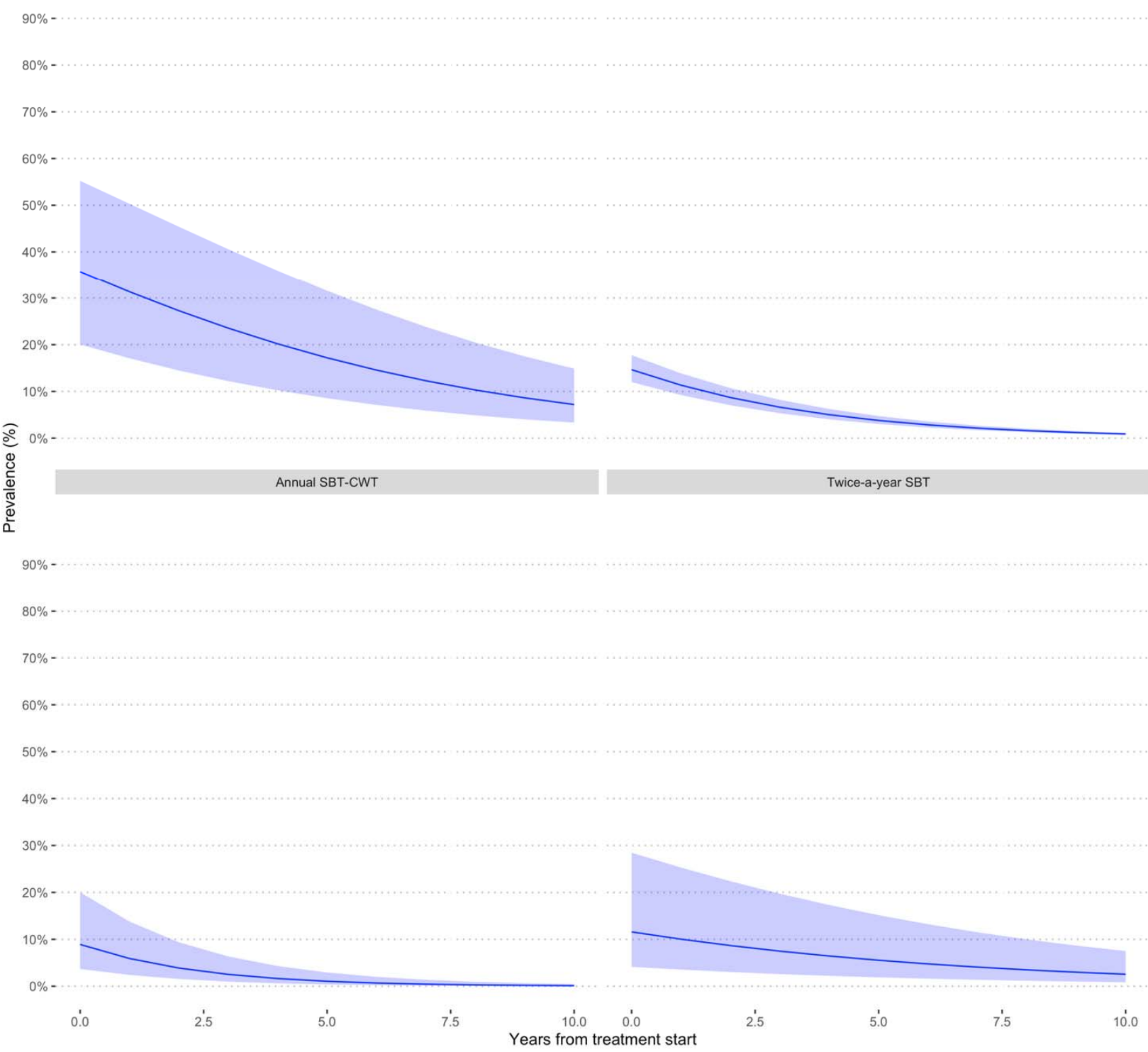

Fig. 10c Estimated prevalence at baseline and at different follow-up times during MDA involving school-age children for $S$. haematobium. All the studies used PZQ $40 \mathrm{mg} / \mathrm{kg}$ administered as a single oral dose alone or in combination with Albendazole (400 mg) in MDA campaigns in endemic countries in Sub-Saharan Africa. 
medRxiv preprint doi: https://doi.org/10.1101/2021.05.10.21256643; this version posted May 15, 2021. The copyright holder for this preprint (which was not certified by peer review) is the author/funder, who has granted medRxiv a license to display the preprint in perpetuity.

It is made available under a CC-BY-NC-ND 4.0 International license .

\section{S. haematobium - Adults}

\section{Annual SBT}

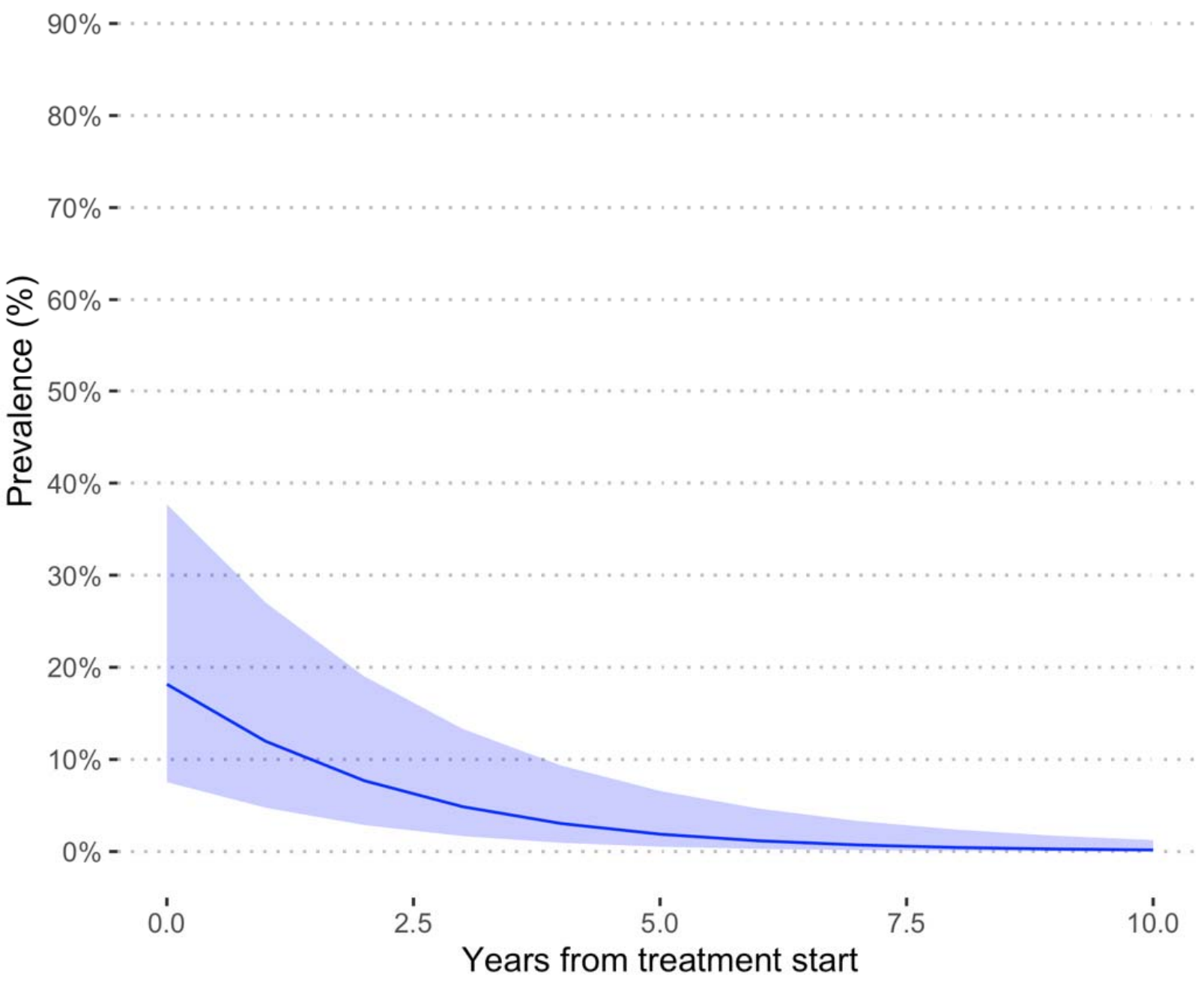

Fig. 10d Estimated prevalence at baseline and at different follow-up times during MDA involving Adults for $S$. haematobium. All the studies used PZQ $40 \mathrm{mg} / \mathrm{kg}$ administered as a single oral dose alone or in combination with Albendazole (400 mg) in MDA campaigns in endemic countries in Sub-Saharan Africa. 
medRxiv preprint doi: https://doi.org/10.1101/2021.05.10.21256643; this version posted May 15, 2021. The copyright holder for this preprint (which was not certified by peer review) is the author/funder, who has granted medRxiv a license to display the preprint in perpetuity.

It is made available under a CC-BY-NC-ND 4.0 International license .

S. mansoni - Annual SBT SAC

$50 \%-$

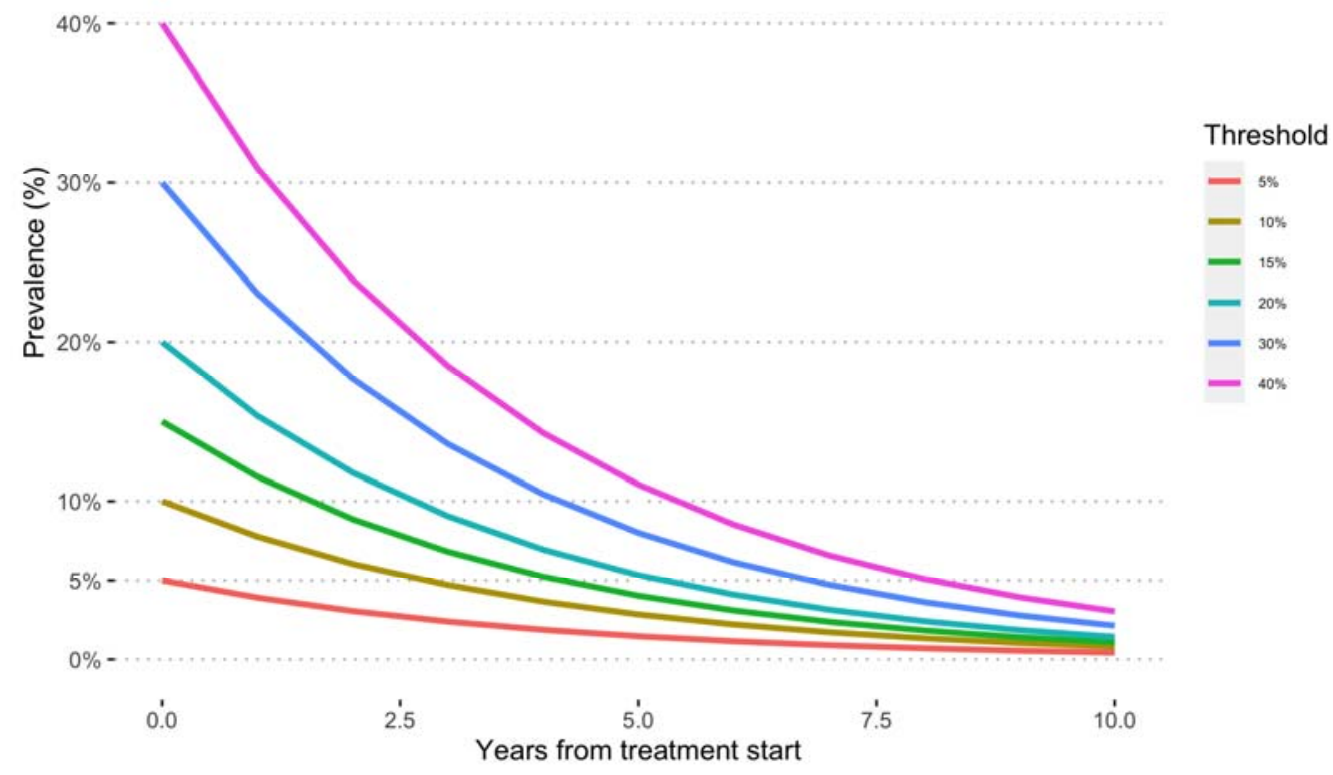

S. mansoni - Annual CWT SAC

$50 \%-$

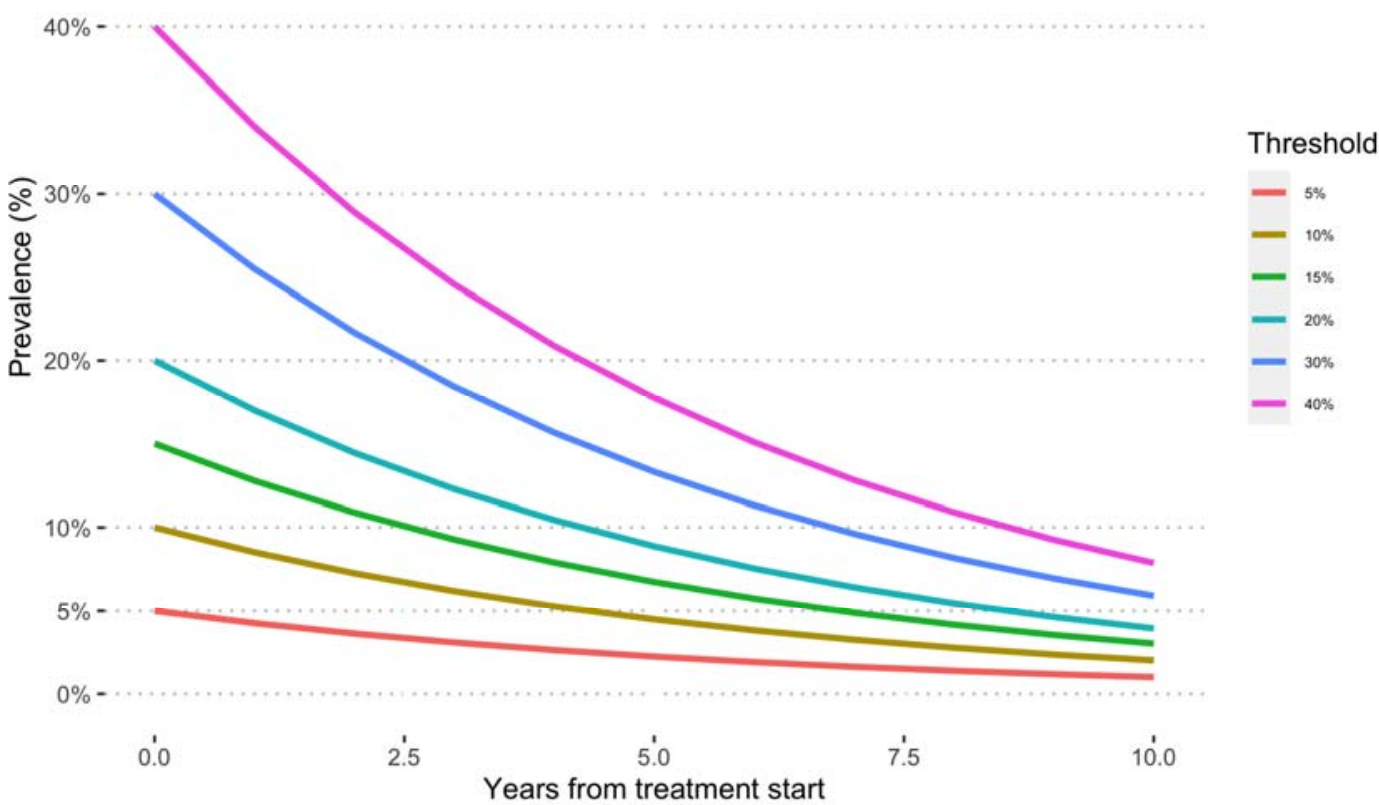

Fig 12a Expected prevalence rates reduction in SAC MDAs for S. mansoni according to longitudinal analyses. Different lines represent different thresholds. SBT stands for School-Based Treatment and

CWT

for

Community-Wide

Treatment. 
medRxiv preprint doi: https://doi.org/10.1101/2021.05.10.21256643; this version posted May 15, 2021. The copyright holder for this preprint (which was not certified by peer review) is the author/funder, who has granted medRxiv a license to display the preprint in perpetuity.

It is made available under a CC-BY-NC-ND 4.0 International license .

S. haematobium - Annual SBT SAC

$50 \%-$

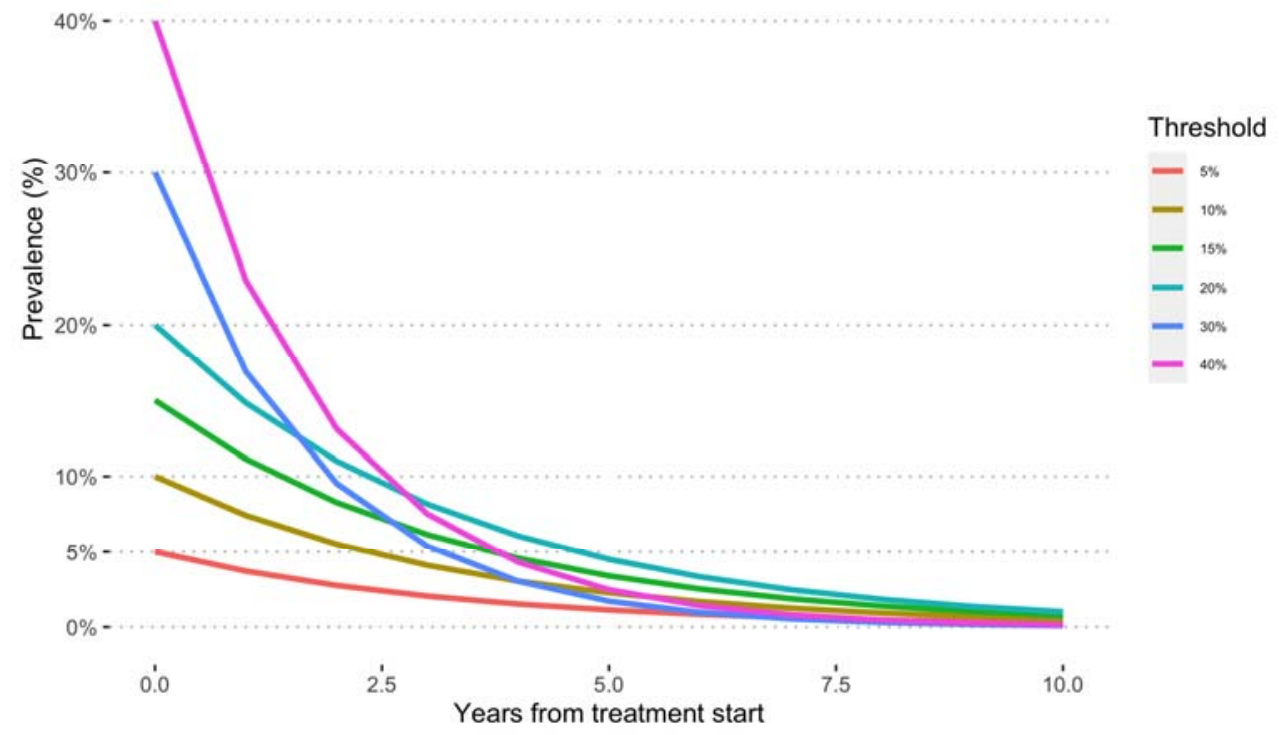

S. haematobium - Annual CWT SAC

$50 \%-$

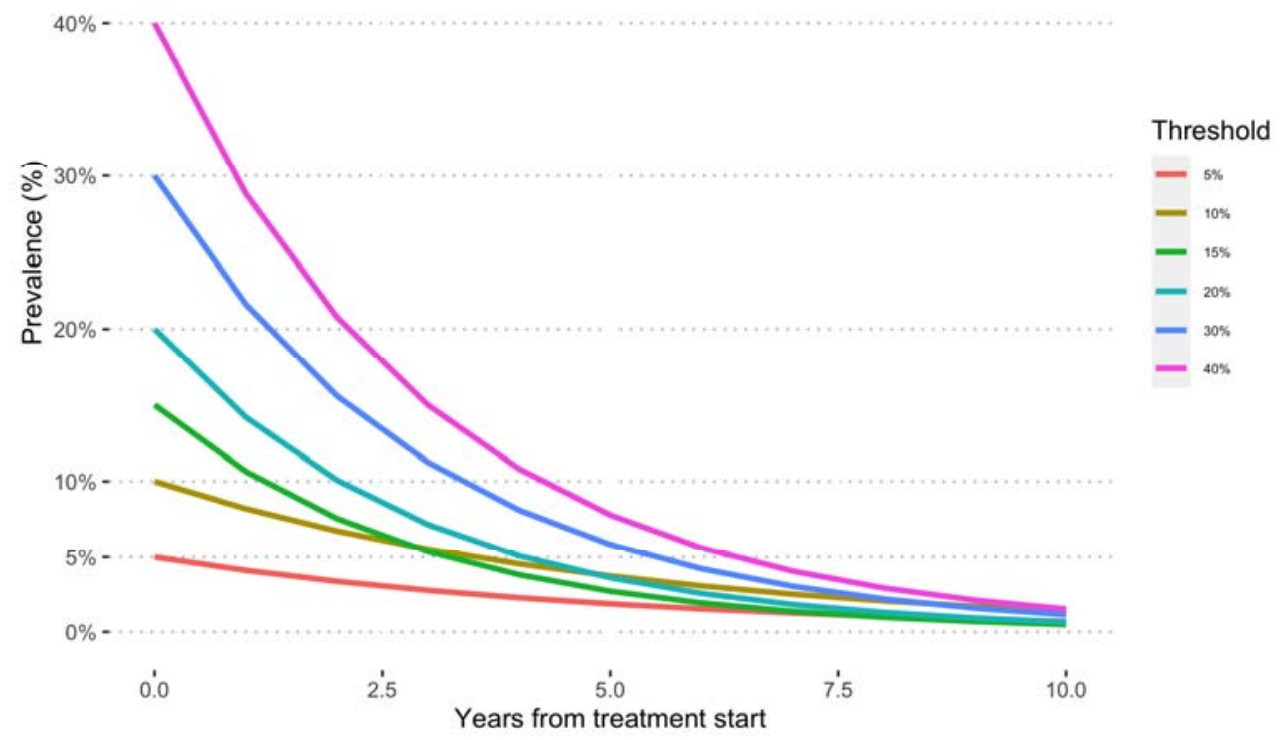

Fig. 12b Expected prevalence rates in SAC MDAs for S. haematobium according to longitudinal analyses. Different lines represent different thresholds. SBT stands for School Based Treatment and CWT for Community Wide Treatment. 
medRxiv preprint doi: https://doi.org/10.1101/2021.05.10.21256643; this version posted May 15, 2021. The copyright holder for this preprint (which was not certified by peer review) is the author/funder, who has granted medRxiv a license to display the preprint in perpetuity. It is made available under a CC-BY-NC-ND 4.0 International license .

\section{Risk of Bias Assessment}

The risk of bias in the included studies has been represented graphically (Fig. 13). Thirty-four studies were assessed to be of low Risk of Bias due to confounding and selection of participants into the study, bias in classification of interventions bias due to deviations from intended interventions and bias in selection of the reported results. For Bias in measurement of outcomes, all the studies were considered to have moderate bias whilst only three studies had information on missing data and scoring moderate; the rest did not report on missing data. None of the studies had high risk of bias, all were assessed to have moderate risk (Table 7).

Of the 34 studies included in the meta-analysis, all of them had low risk of bias due to confounding, low risk of bias due in selection of participants, low risk of bias in the classification of intervention, low risk of bias due to due to deviations from intended interventions and low risk of bias in selective reporting of outcomes. All the 34 studies showed moderate risk of bias in measurement of outcomes. None of the studies had serious or critical risk of bias in them (Table 7).

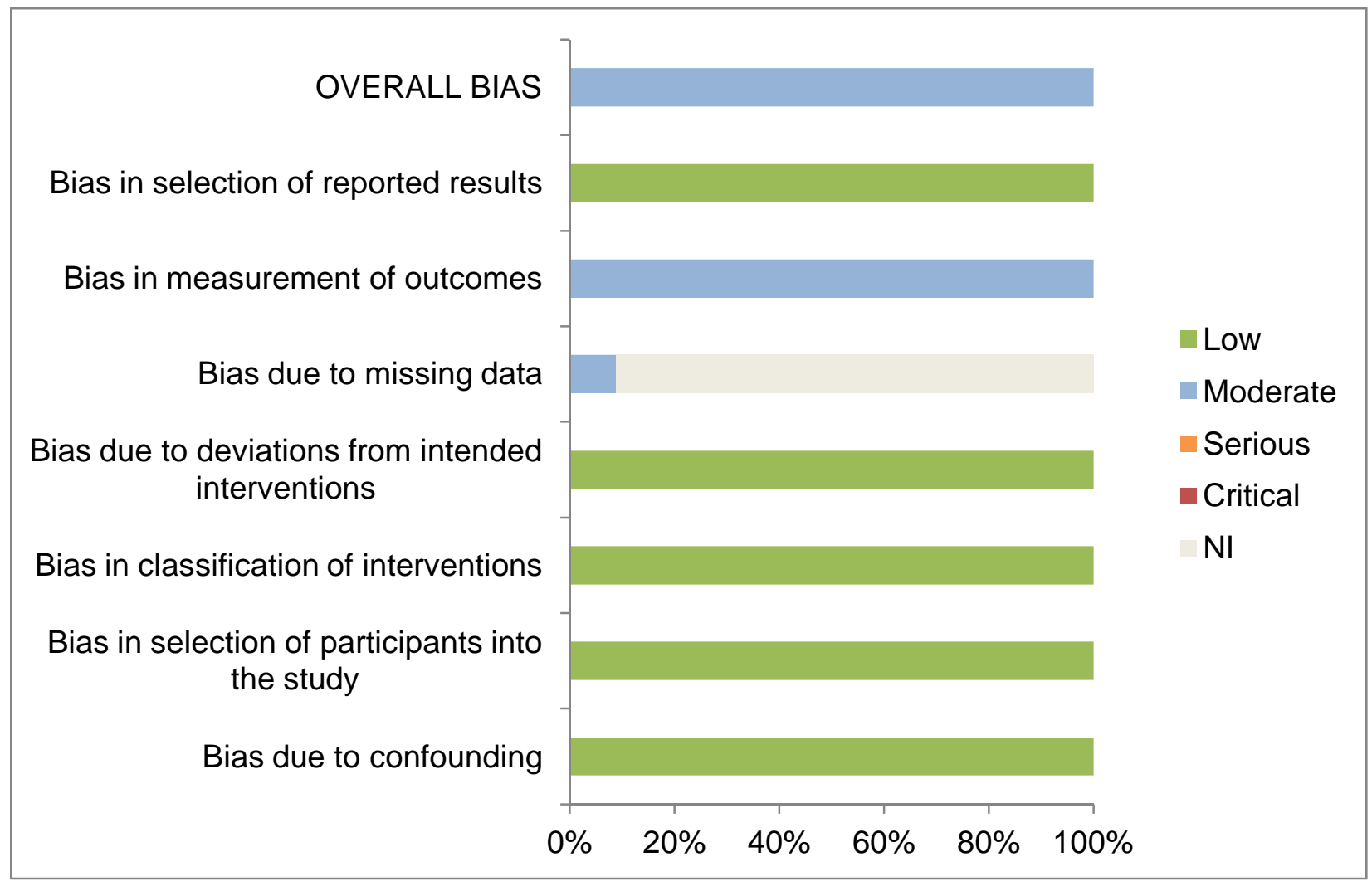

Figure 13 Graphical representation of Risk of bias in the included studies in the systematic review 
Table 7 Results of risk of bias assessment of the studies included in the systematic review

\section{Study}

Bias due to

selection of participants
Bias in

Bias due to

deviations

from intended interventions

Abudho et al., 2018

Assare et al., 2016

Bah et al., 2019

Brinkmann et al., 1988

Bronzan et al., 2015

Hamidou et al., 2018

Hodges et al., 2012

Karanja et al., 2017

Knopp et al., 2019

Lee et al., 2015

Moussa et al., 2016

Mwandawiro et al., 2019

Mwinzi et al., 2012

Njenga et al.,2014

Olsen et al., 2018

Onkanga et al., 2016

Ouedraogo et al., 2016

Phillips et al., 2017

\begin{tabular}{|c|c|c|c|}
\hline Low & Low & Low & Low \\
\hline Low & Low & Low & Low \\
\hline Low & Low & Low & Low \\
\hline Low & Low & Low & Low \\
\hline Low & Low & Low & Low \\
\hline Low & Low & Low & Low \\
\hline Low & Low & Low & Low \\
\hline Low & Low & Low & Low \\
\hline Low & Low & Low & Low \\
\hline Low & Low & Low & Low \\
\hline Low & Low & Low & Low \\
\hline Low & Low & Low & Low \\
\hline Low & Low & Low & Low \\
\hline Low & Low & Low & Low \\
\hline Low & Low & Low & Low \\
\hline Low & Low & Low & Low \\
\hline Low & Low & Low & Low \\
\hline Low & Low & Low & Low \\
\hline
\end{tabular}

Bias due to

missing data

NI*
Moderate
NI
NI

Moderate

NI

NI

NI

NI

NI

NI

NI

NI

NI

NI

NI

NI

NI

NI

Moderate
Bias in

measurement of outcomes

Moderate

Moderate

Moderate

Moderate

Moderate

Moderate

Moderate

Moderate

Moderate

Moderate

Moderate

Moderate

Moderate

Moderate

Moderate

Moderate

Moderate

Moderate
Bias in selection of reported results

OVERALL

(

Moderate

Moderate

Moderate-

$\stackrel{\oplus}{=}$

Modera熙家

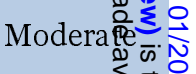

Toder

Modera整罂

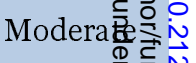

Moderate

Moderater

ก๊

Moderate⿳亠丷厂犬⿺

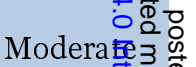

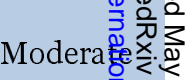

ஹ

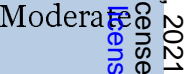

Moderafe혀검

Moderate $\underset{\frac{0}{0}}{\frac{0}{2}}$

Moderateo

Moderate

Moderate $\frac{\Phi}{\bar{\Phi}}$ के 


\section{SCI-supported MDA 1}

SCI-supported MDA 2

SCI-supported MDA 3

SCI-supported MDA 4

SCI-supported MDA 5

SCI-supported MDA 6

SCI-supported MDA 7

SCI-supported MDA 8

SCI-supported MDA 9

SCI-supported MDA 10

Secor et al., 2020

Senghor et al., 2016

Sesay et al., 2014

Shen et al., 2019

Sircar et al. 2018

Zhang et al., 2007

Low

Moderate

Serious

Critical

* No information (NI)

\begin{tabular}{|c|c|c|c|}
\hline Low & Low & Low & Low \\
\hline Low & Low & Low & Low \\
\hline Low & Low & Low & Low \\
\hline Low & Low & Low & Low \\
\hline Low & Low & Low & Low \\
\hline Low & Low & Low & Low \\
\hline Low & Low & Low & Low \\
\hline Low & Low & Low & Low \\
\hline Low & Low & Low & Low \\
\hline Low & Low & Low & Low \\
\hline Low & Low & Low & Low \\
\hline Low & Low & Low & Low \\
\hline Low & Low & Low & Low \\
\hline Low & Low & Low & Low \\
\hline Low & Low & Low & Low \\
\hline Low & Low & Low & Low \\
\hline
\end{tabular}

34

o

o

o

o
34

o

o

o

o

NI

\begin{tabular}{l} 
NI \\
NI \\
NI \\
NI \\
NI \\
NI \\
NI \\
NI \\
NI \\
NI \\
NI \\
NI \\
\hline
\end{tabular}

o

3

o

o

31

\begin{tabular}{|c|c|}
\hline Moderate & Low \\
\hline Moderate & Low \\
\hline Moderate & Low \\
\hline Moderate & Low \\
\hline Moderate & Low \\
\hline Moderate & Low \\
\hline Moderate & Low \\
\hline Moderate & Low \\
\hline Moderate & Low \\
\hline Moderate & Low \\
\hline Moderate & Low \\
\hline Moderate & Low \\
\hline Moderate & Low \\
\hline Moderate & Low \\
\hline Moderate & Low \\
\hline Moderate & Low \\
\hline
\end{tabular}

o

34

o

o

o

34

o

o

o

o
Moderate

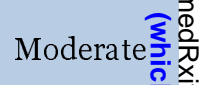

Moderate

Moderate $\frac{0}{\Omega}$ 응.

Moderate

Moderate $\frac{0}{0} \frac{0}{0}$.

Moderate

Moderate

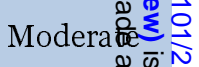

Modera离家芥

Moderage $\frac{0}{0} \frac{\text { o }}{5}$

Modera整鱼

Moderate용

एٔt

Moderate현.

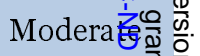

Moderate

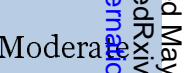

Modera行

0 D

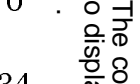

34

o

o

o

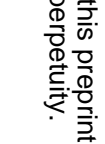




\section{PICOS}

\begin{tabular}{|l|}
\hline Population \\
\hline - Whole population or subgroups (Pre-SAC, SAC, adults including pregnant and lactating women) infected with any of the \\
schistosome species or non-infected, living in endemic areas who received PZQ during a PC or MDA programme
\end{tabular}




\begin{tabular}{|c|c|c|c|c|c|c|}
\hline \multicolumn{7}{|c|}{$\begin{array}{l}\text { Anticipated absolute effects* } \\
(95 \% \text { CI })\end{array}$} \\
\hline Outcomes & $\begin{array}{c}\text { Without } \\
\text { preventive } \\
\text { chemotherapy }\end{array}$ & $\begin{array}{c}\text { With } \\
\text { preventive } \\
\text { chemotherapy }\end{array}$ & $\begin{array}{c}\text { Relative } \\
\text { effect } \\
(95 \% \mathrm{CI})\end{array}$ & $\begin{array}{l}\text { Number of } \\
\text { participant } \\
\text { s (studies) }\end{array}$ & $\begin{array}{c}\text { Quality of the } \\
\text { evidence (GRADE) }\end{array}$ & Comments \\
\hline $\begin{array}{l}\text { One-year prevalence reduction } \\
\text { of } S . \text { mansoni in SAC } \\
\text { (Annual SBT; } 0 \text { to } 1 \text { year) }\end{array}$ & $\begin{array}{c}8,155 / 45,510 \\
(17.9 \%)\end{array}$ & $\begin{array}{c}5,047 / 40,563 \\
(12.4 \%)\end{array}$ & $\begin{array}{c}\mathrm{PR}=0.56 \\
(0.46 \text { to } 0.69)\end{array}$ & $\begin{array}{c}45,510 \\
(14)\end{array}$ & $\oplus \oplus \oplus \odot$ & NA \\
\hline $\begin{array}{l}4 \text { years prevalence reduction } \\
\text { of } S . \text { mansoni in } \mathrm{SAC} \\
\text { (Annual SBT; } 0 \text { to } 4 \text { year) }\end{array}$ & $\begin{array}{c}3,936 / 17,745 \\
(22.2 \%)\end{array}$ & $\begin{array}{c}1,196 / 9,738 \\
(12.3 \%)\end{array}$ & $\begin{array}{c}\mathrm{PR}=0.25 \\
(0.11 \text { to } 0.59)\end{array}$ & $\begin{array}{c}17,745 \\
(5)\end{array}$ & $\oplus \oplus \oplus \odot$ & NA \\
\hline $\begin{array}{l}\text { Annual prevalence reduction } \\
\text { of } S . \text { mansoni in SAC } \\
\text { (Annual SBT; Threshold >5\%; } \\
\text { follow-up: range } 1-7 \text { years) }\end{array}$ & - & - & $\begin{array}{c}\mathrm{PR}=0.78 \\
(0.77 \text { to } 0.79)\end{array}$ & $\begin{array}{c}123,045 \\
(20)\end{array}$ & $\oplus \oplus \oplus \odot$ & NA \\
\hline $\begin{array}{l}\text { One-year prevalence reduction } \\
\text { of } S . \text { haematobium in SAC } \\
\text { (Annual SBT; } 0 \text { to } 1 \text { year) }\end{array}$ & $\begin{array}{l}6,582 / 20,040 \\
\quad(32.8 \%)\end{array}$ & $\begin{array}{c}3,027 / 17,828 \\
(17.0 \%)\end{array}$ & $\begin{array}{c}\mathrm{PR}=0.38 \\
(0.28 \text { to } 0.52)\end{array}$ & $\begin{array}{c}20,040 \\
(8)\end{array}$ & $\oplus \oplus \oplus \odot$ & NA \\
\hline $\begin{array}{l}4 \text { years prevalence reduction } \\
\text { of } S \text {. haematobium in SAC } \\
\text { (Annual SBT; } 0 \text { to } 4 \text { years) }\end{array}$ & $\begin{array}{c}1,387 / 6,274 \\
(22.1 \%)\end{array}$ & $\begin{array}{c}949 / 4,680 \\
(20.3 \%)\end{array}$ & $\begin{array}{c}\mathrm{PR}=0.38 \\
(0.28 \text { to } 0.52)\end{array}$ & $\begin{array}{c}6,724 \\
(2)\end{array}$ & $\oplus \oplus \odot \odot$ & NA \\
\hline $\begin{array}{l}\text { Annual prevalence reduction } \\
\text { of } S . \text { haematobium in SAC } \\
\text { (Annual SBT; Threshold >5\%; } \\
\text { follow-up: range } 1-7 \text { years) }\end{array}$ & - & - & $\begin{array}{c}\mathrm{PR}=0.74 \\
(0.73 \text { to } 0.75)\end{array}$ & $\begin{array}{c}106,912 \\
(13)\end{array}$ & $\oplus \oplus \oplus \odot$ & NA \\
\hline
\end{tabular}

GRADE Working Group grades of evidence (Guyatt et al., 2013)

$\oplus \oplus \oplus \oplus$ High quality: We are very confident that the true effect lies close to that of the estimate of effect.

$\oplus \oplus \oplus \odot$ Moderate quality: We are moderately confident in the effect estimate: The true effect is likely to be close to the estimate of the effect, but there is a

possibility that it is substantially different. 
medRxiv preprint doi: https://doi.org/10.1101/2021.05.10.21256643; this version posted May 15, 2021. The copyright holder for this preprint

(which was not certified by peer review) is the author/funder, who has granted medRxiv a license to display the preprint in perpetuity.

It is made available under a CC-BY-NC-ND 4.0 International license .

\section{Discussion}

This systematic review and meta-analysis showed the relationship between prevalence and intensity of infection is not linear, but a quadratic polynomial relationship. Obviously, this has implications for policy and control. The pooled data come from thousands of communities representing the diversity of demography, settings and schistosome dynamics and, therefore, informative. Also, given that the assumed linear relationship held by many may not be accurate means that caution should be exercised when justifying the use of prevalence as a proxy for determining the threshold upon which to justify an MDA. We suggest more rigorous work that attempts to conduct a head-to-head comparison of prevalence and intensity is warranted to ascertain which of the two measures is more stable and responsive across settings and contexts to measure the effect of MDA.

The results also showed that when given as annual MDA, the prevalence of $S$. mansoni and $S$. haematobium in school-age children decreases, but no apparent difference between baseline and 48 months. Similarly, annual MDA for S. mansoni achieved a reduction for SAC and adults but no apparent further reduction after 12 months by repeated MDA. Community-wide treatment sowed similar results. Annual mass drug administration for up to 9 years did not achieve prevalence reduction to the elimination target for $S$. mansoni in settings with baseline prevalence $\geq 10 \%$. For $S$. haematobium, although annual mass drug administration up to 5 years reduced prevalence to lower levels than $S$. mansoni, elimination target was not reached in setting with baseline prevalence $\geq 10 \%$ by 10 years of mass drug administration. From extrapolated findings, up to 15 years of annual whole community mass drug administration will be required to achieve elimination when baseline prevalence is $\geq 10 \%$. Further analyses using a series of prevalence thresholds showed no apparent difference in the time to elimination between $5 \%$ and 10\%, 15\%, $20 \%, 30 \%$ and $40 \%$, but higher than $10 \%$ thresholds took longer to achieve elimination.

Heterogeneity between the studies pooled was high $\left(I^{2}>97 \%\right)$, but given the huge number of studies and individuals treated, this is not likely to influence the study conclusions. This could explain 'real' differences between MDA programmes, which is what the $I^{2}$ is measuring. In terms of strategy, some MDA programmes treated only SAC (sbt), SAC and occupationally at-risk adults (SAC and adults) or community-wide treatment (cwt). In some settings, other control measures that took place during the same period of the MDA, villages differed in baseline intensity of infection and thereby force of transmission, variation in sensitivities in diagnostic criteria existed between MDA programmes as well as differences in follow-up times after MDA. As data on some of these factors were not documented or in formats that could be used, these variations could not be quantitatively addressed in the meta-analysis or sub-group analysis.

Heterogeneity between the studies pooled in this meta-analysis was high $\left(I^{2}>95 \%\right.$ in most of the analysis) but given the huge number of studies and individuals treated, between studies heterogeneity is not expected to change the direction of treatment effect or the overall conclusions from this review. The high levels of heterogeneity could be explained by the following: 1) there are 'real' differences between MDA programmes, so the $I^{2}$ values are a true 
medRxiv preprint doi: https://doi.org/10.1101/2021.05.10.21256643; this version posted May 15, 2021. The copyright holder for this preprint (which was not certified by peer review) is the author/funder, who has granted medRxiv a license to display the preprint in perpetuity. It is made available under a CC-BY-NC-ND 4.0 International license .

reflection, 2) MDA programmes differed in strategy (some treated only SAC, SAC and occupationally at-risk adults (SAC and adults) or community-wide treatment, 3) other control measures took place during the period of the MDA in some cases but not accounted for in reporting the results of MDAs, 4) villages differed in baseline intensity of infection and thereby force of transmission, 5) variation in sensitivities in diagnostic criteria existed between MDA programmes, and 6) differences existed in follow-up times of MDAs.

Data on some of these factors were not documented or presented in formats that could be used in this systematic review and meta-analysis, and therefore, some of these variations could not be quantitatively addressed in the meta-analysis or in sub-group analyses.

\section{Conclusions and recommendations}

The evidence presented in this review (given ethical implications) suggests that $10 \%$ prevalence can be used as the 'global' prevalence threshold for MDA in endemic countries.

- Most of the data are from SAC population; no data on pre-school children and few on adults make it difficult to make a concrete statement about the generalizability of the review findings beyond SAC.

- From this review, PZQ appears to be effective in reducing the prevalence of schistosomiasis at 12 months, but the incremental benefit of repeated annual treatment appears to be minimal in further reducing prevalence over time

- In both light prevalence and intensity, infection rates do not decrease but rather tended to increase with biennial MDA

- Effectiveness depends on several factors, which are difficult to disentangle. However, the rate of prevalence decrease seems not influenced by the baseline intensity of infection and type of treatment

- Further analyses were conducted from a series of created prevalence thresholds of 5\%, 10\%, $15 \%, 20 \%, 30 \%$ and $\geq 40 \%$ and although showed differences in the effect of MDA, the differences in effect based on threshold regressed over time (after about 8 years). For the annual MDA of SAC, SBT appears to perform better than CWT in terms of prevalence reduction. For schistosome species, the model suggests, using the same prevalence threshold, it will take shorter time to reach elimination for S. haematobium than S. mansoni; annual MDA for $S$. haematobium (SBT) will require about 10 years to achieve elimination whereas it will take longer for $S$. mansoni (over 10 years to around 15 years to achieve elimination).

- The question that remains is what happens to endemic communities/settings with less than $10 \%$ prevalence?

- Integration of non-pharmacological interventions such as access to water, improved sanitation, hygiene education (WASH) and snail control will complement MDA to achieve the elimination of schistosomiasis. 
medRxiv preprint doi: https://doi.org/10.1101/2021.05.10.21256643; this version posted May 15, 2021. The copyright holder for this preprint

(which was not certified by peer review) is the author/funder, who has granted medRxiv a license to display the preprint in perpetuity.

It is made available under a CC-BY-NC-ND 4.0 International license .

\section{REFERENCES}

\section{INCLUDED STUDIES}

Abudho BO, Ndombi EM, Guya B, Carter JM, Riner DK, Kittur N, Karanja DMS, Secor WE, Colley DG. Impact of Four Years of Annual Mass Drug Administration on Prevalence and Intensity of Schistosomiasis among Primary and High School Children in Western Kenya: A Repeated Cross-Sectional Study. Am. J. Trop. Med. Hyg., 98(5), 2018, 13971402

Assaré RK, Tian-Bi YN, Yao PK, N'Guessan NA, Ouattara M, Yapi A, Coulibaly JT, Meïté A, Hürlimann E, Knopp S, Utzinger J, N'Goran EK. Sustaining Control of Schistosomiasis Mansoni in Western Côte d'Ivoire: Results from a SCORE Study, One Year after Initial Praziquantel Administration. PLoS Negl Trop Dis. 2016 Jan 20;10(1):e0004329. doi: 10.1371/journal.pntd.0004329. eCollection 2016 Jan.

Bronzan RN, Dorkenoo AM, Agbo YM, Halatoko W, Layibo Y, Adjeloh P, et al. Impact of community-based integrated mass drug administration on schistosomiasis and soiltransmitted helminth prevalence in Togo. PLoS Negl Trop Dis 2018,12(8): e0006551. https://doi.org/10.1371/journal.pntd.0006551

Karanja DMS, Awino EK, Wiegand RE, Okoth E, Abudho BO, Mwinzi PNM, Montgomery SP, Secor WE. Cluster randomized trial comparing school-based mass drug administration schedules in areas of western Kenya with moderate initial prevalence of Schistosoma mansoni infections. PLoS Negl Trop Dis 2017; 11(10): e0006033. https://doi.org/10.1371/journal.pntd.0006033

Ouedraogo H, Drabo F, Zongo D, Bagayan M, Bamba I, Pima T, Yago-Wienne F, Toubali E, Zhang Y. Schistosomiasis in school-age children in Burkina Faso after a decade of preventive chemotherapy. Bull World Health Organ. 2016 Jan 1;94(1):37-45. doi: 10.2471/BLT.15.161885. Epub 2015 Nov 24.

Schutte CHJ, Evans AC, Pammenter MD, Cooppan RM, Pretorius SJ, Joubert PH. Epidemiology and control of schistosomiasis mansoni in communities living on the Cuondo River Floodplains of East Caprivi, Namibia. Annals of Tropical Medicine, 1995; vol 89, 6:631644

Sesay S, Paye J, Bah MS, McCarthy FM, Conteh A, Sonnie M, Hodges MH, Zhang Y. Schistosoma mansoni infection after three years of mass drug administration in Sierra Leone. Parasit Vectors. 2014 Jan 9;7:14. doi: 10.1186/1756-3305-7-14.

Onkanga IO, Mwinzi PN, Muchiri G, Andiego K, Omedo M, Karanja DM, Wiegand RE, Secor WE, Montgomery SP. Impact of two rounds of praziquantel mass drug administration on Schistosoma mansoni infection prevalence and intensity: a comparison between community wide treatment and school based treatment in western Kenya. Int J Parasitol. 2016 Jun;46(7):439-45. doi: 10.1016/j.ijpara.2016.01.006. Epub 2016 Mar 2.

Wiegand RE, Mwinzi PNM, Montgomery SP, Chan YL, Andiego K, Omedo M, Muchiri G, Ogutu MO, Rawago F, Odiere MR, Karanja DMS, Secor WE. A Persistent Hotspot of Schistosoma mansoni Infection in a Five-Year Randomized Trial of Praziquantel Preventative Chemotherapy Strategies. J Infect Dis. 2017 Dec 12;216(11):1425-1433. doi: 10.1093/infdis/jix496.

Zhang Y1, Koukounari A, Kabatereine N, Fleming F, Kazibwe F, Tukahebwa E, Stothard JR, Webster JP, Fenwick A. Parasitological impact of 2-year preventive chemotherapy on schistosomiasis and soil-transmitted helminthiasis in Uganda. BMC Med. 2007 Sep 3;5:27. 
medRxiv preprint doi: https://doi.org/10.1101/2021.05.10.21256643; this version posted May 15, 2021. The copyright holder for this preprint

(which was not certified by peer review) is the author/funder, who has granted medRxiv a license to display the preprint in perpetuity.

It is made available under a CC-BY-NC-ND 4.0 International license .

Hodges MH, Dada N, Warmsley A, Paye J, Bangura MM, Nyorkor E, Sonnie M, Zhang Y. Mass drug administration significantly reduces infection of Schistosoma mansoni and hookworm in school children in the national control program in Sierra Leone. BMC Infectious Diseases 2012, 12:16, http://www.biomedcentral.com/1471-2334/12/16

Phillips AE, Gazzinelli-Guimaraes PH, Aurelio HO, Ferro J, Nala R, Clements M, King CH, Fenwick A, Fleming FM, Dhanani N. Assessing the benefits of five years of different approaches to treatment of urogenital schistosomiasis: A SCORE project in Northern Mozambique. PLoS Negl Trop Dis. 2017 Dec 8;11(12):e0006061. doi: 10.1371/journal.pntd.0006061. eCollection 2017 Dec.

Hamidou AA, Tohon Z, Sofo B, Dhanani NA, Gnandou I, Sidikou B, Noma AG, Madougou B, Alto O, Sebangou H, Kader M, Andia HR, Garba A, Fenwick A, Phillips AE. Evaluating the impact of biannual treatment on urogenital schistosomiasis in Niger. Report, Unpublished

Garba A, Barkiré N, Djibo A, Lamine MS, Sofo B, Gouvras AN, Bosqué-Oliva E, Webster JP, Stothard JR, Utzinger J, Fenwick A. Schistosomiasis in infants and preschool-aged children: Infection in a single Schistosoma haematobium and a mixed S. haematobium-S. mansoni foci of Niger. Acta Trop. 2010 Sep;115(3):212-9. doi: 10.1016/j.actatropica.2010.03.005. Epub 2010 Mar 19.

Senghor B, Diaw OT, Doucoure S, Seye M, Diallo A, Talla I, Bâ CT, Sokhna C. Impact of Annual Praziquantel Treatment on Urogenital Schistosomiasis in a Seasonal Transmission Focus in Central Senegal. PLoS Negl Trop Dis. 2016 Mar 25;10(3):e0004557. doi: 10.1371/journal.pntd.0004557. eCollection 2016 Mar.

Njenga SM, Mutungi FM, Wamae CN, Mwanje MT, Njiru KK, Bockarie MJ. Once a year school-based deworming with praziquantel and albendazole combination may not be adequate for control of urogenital schistosomiasis and hookworm infection in Matuga District, Kwale County, Kenya, Report, Unpublished

Mwinzi PN, Montgomery SP, Owaga CO, Mwanje M, Muok EM, Ayisi JG, Laserson KF, Muchiri EM, Secor WE, Karanja DM.Integrated community-directed intervention for schistosomiasis and soil transmitted helminths in western Kenya - a pilot study. Parasit Vectors. 2012 Aug 31;5:182.

Mwinzi PN, Muchiri G, Wiegand RE, Omedo M, Abudho B, Karanja DM, Montgomery SP, Secor WE. Predictive Value of School-Aged Children's Schistosomiasis Prevalence and Egg Intensity for Other Age Groups in Western Kenya. Am J Trop Med Hyg. 2015 Dec;93(6):1311-7. doi: 10.4269/ajtmh.15-0467. Epub 2015 Sep 28.

Ortu G, Khan J, Samuel Yibi M, Abdu Nimaya I. Mass drug administration in Central Equatoria, South Sudan: results and suggestions for future distributions. Int Health. $2017 \mathrm{Jul}$ 1;9(4):263-266. doi: 10.1093/inthealth/ihx025.

Sircar AD, Mwinzi PNM, Onkanga IO, Wiegand RE, Montgomery SP, Secor WE1.Schistosoma mansoni Mass Drug Administration Regimens and Their Effect on Morbidity among Schoolchildren over a 5-Year Period-Kenya, 2010-2015. Am J Trop Med Hyg. 2018 Aug;99(2):362-369. doi: 10.4269/ajtmh.18-0067. Epub 2018 Jun 7. 
medRxiv preprint doi: https://doi.org/10.1101/2021.05.10.21256643; this version posted May 15, 2021. The copyright holder for this preprint

(which was not certified by peer review) is the author/funder, who has granted medRxiv a license to display the preprint in perpetuity.

It is made available under a CC-BY-NC-ND 4.0 International license .

Kheir MM, Baraka OZ, El-Tom IA, Mukhtar MM, Homeida MMA. Effects of single-dose praziquantel on morbidity and mortality resulting from intestinal schistosomiasis. Eastern Mediterranean Health Journal, 2000; vol 6, 5-6:927-931

Kittur N, Binder S, Campbell CH, King CH, Kinung'hi S, Olsen A, Magnussen P, Colley DG. Defining Persistent Hotspots: Areas That Fail to Decrease Meaningfully in Prevalence after Multiple Years of Mass Drug Administration with Praziquantel for Control of Schistosomiasis. Am J Trop Med Hyg. 2017 Dec;97(6):1810-1817. doi: 10.4269/ajtmh.17-0368. Epub 2017 Sep 21.

Landouré A, Dembélé R, Goita S, Kané M, Tuinsma M, Sacko M, Toubali E, French MD, Keita AD, Fenwick A, Traoré MS, Zhang Y. Significantly reduced intensity of infection but persistent prevalence of schistosomiasis in a highly endemic region in Mali after repeated treatment. PLoS Negl Trop Dis. 2012;6(7):e1774. doi: 10.1371/journal.pntd.0001774. Epub 2012 Jul 31.

Lee YH, Jeong HG, Kong WH, Lee SH, Cho HI, Nam HS, Ismail HA, Alla GN, Oh CH, Hong ST. Reduction of urogenital schistosomiasis with an integrated control project in Sudan. PLoS Negl Trop Dis. 2015 Jan 8;9(1):e3423. doi: 10.1371/journal.pntd.0003423. eCollection 2015 Jan.

Midzi N, Mtapuri-Zinyowera S, Sangweme D, Paul NH, Makware G, Mapingure MP, Brouwer KC, Mudzori J, Hlerema G, Chadukura V, Mutapi F, Kumar N, Mduluza T. Efficacy of integrated school based de-worming and prompt malaria treatment on helminths Plasmodium falciparum co-infections: A 33 months follow up study. BMC Int Health Hum Rights. 2011 Jun 22;11:9. doi: 10.1186/1472-698X-11-9.

Moussa A, Babacar F, Darnycka BMR, Clément TR, Oumar G. Effectiveness of Semestrial Mass Administration of Praziquantel $600 \mathrm{mg}$ in the Schistosomiasis High Transmission Areas of Senegal River Basin. International Journal of TROPICAL DISEASE \& Health 17(3): 1-7, 2016, Article no.IJTDH.27007 ISSN: 2278-1005, NLM ID: 101632866, SCIENCEDOMAIN international: www.sciencedomain.org

\section{OTHER REFERENCES}

Alonso-Coello P, Schünemann HJ, Moberg J, Brignardello-Petersen R, Akl EA, Davoli M, Treweek S, Mustafa RA, Rada G, Rosenbaum S, Morelli A, Guyatt GH, Oxman AD; GRADE Working Group. GRADE Evidence to Decision (EtD) frameworks: a systematic and transparent approach to making well informed healthcare choices. 1: Introduction. BMJ. 2016 Jun 28;353:i2016. doi: 10.1136/bmj.i2016. No abstract available.

Bärenbold O, Garba A, Colley DG, Fleming FM, Haggag AA, Ramzy RMR, Assaré RK, Tukahebwa $\quad$ EM, Mbonigaba JB, Bucumi V, Kebede B, Yibi MS, Meité A, Coulibaly JT, N'Goran EK, Tchuem Tchuenté LA, Mwinzi P, Utzinger J, Vounatsou P. Translating preventive chemotherapy prevalence thresholds for Schistosoma mansoni from the Kato-Katz technique into the point-of-care circulating cathodic antigen diagnostic test. PLoS Negl Trop Dis, 2018 Dec 14;12(12):e0006941, doi: 10.1371/journal.pntd.0006941. eCollection 2018 Dec.

Bossuyt P, Davenport C, Deeks J, Hyde C, Leeflang M, Scholten R. Chapter 11: Interpreting results and drawing conclusions. In: Deeks JJ, Bossuyt PM, Gatsonis C, editors. Cochrane 
medRxiv preprint doi: https://doi.org/10.1101/2021.05.10.21256643; this version posted May 15, 2021. The copyright holder for this preprint

(which was not certified by peer review) is the author/funder, who has granted medRxiv a license to display the preprint in perpetuity.

It is made available under a CC-BY-NC-ND 4.0 International license .

handbook for systematic reviews of diagnostic test accuracy, Version 0.9. Oxford: The Cochrane Collaboration; 2013. Available from: http://methods.cochrane.org/sdt/sites/methods.cochrane.org.sdt/files/uploads/DTA\%20Ha ndbook\%20Chapter\%2011\%20201312.pdf

Danso-Appiah A, Minton J, Boamah D, Otchere J, Asmah RH, Rodgers M, Bosompem KM, Eusebi P, De Vlas SJ. Accuracy of point-of-care testing for circulatory cathodic antigen in the detection of schistosome infection: systematic review and meta-analysis. Bull World Health Organ. 2016 Jul 1;94(7):522-533A. doi: 10.2471/BLT.15.158741. Epub 2016 Apr

Danso-Appiah A, De Vlas SJ. Interpreting low praziquantel cure rates of Schistosoma mansoni infections in Senegal. rends Parasitol. 2002 Mar;18(3):125-9. doi: 10.1016/s14714922(01)02209-7.

DerSimonian R, Laird N. Meta-analysis in clinical trials. Control Clin Trials. 1986. September;7(3):177-88. 10.1016/0197-2456(86)90046-2

Eusebi P, Reitsma JB, Vermunt JK. Latent class bivariate model for the meta-analysis of diagnostic test accuracy studies. BMC Med Res Methodol. 2014;14(1):88. 10.1186/14712288-14-88.

Fenwick A, Rollinson D, Southgate V (2006) Implementation of human schistosomiasis control: challenges and prospects. Adv Parasitol 61:567-622.

Fenwick A, Webster JP, Bosque-Oliva E, Blair L, Fleming FM et al (2009) The Schistosomiasis Control Initiative (SCI): rationale, development and implementation from 2002-2008.

Higgins JPT, Green S (editors). Cochrane Handbook for Systematic Reviews of Interventions. Version 5.1.0 [updated March 2011]. The Cochrane Collaboration. www.cochranehandbook.org, 2011.

Hotez PJ. Mass drug administration and integrated control for the world's high-prevalence neglected tropical diseases. Clin Pharmacol Ther 2009; 85:659-664.

Hotez P Enlarging the "Audacious Goal": elimination of the world's high prevalence neglected tropical diseases. Vaccine 2011; 29(Suppl 4):D104-D110. doi:10.1016/j.vaccine.2011.06.024.

Hoy D, Brooks P, Woolf A, et al. Assessing risk of bias in prevalence studies: modification of an existing tool and evidence of interrater agreement. J Clin Epidemiol 2012;65:934-9.

King $\mathrm{CH}$, et al. 2020, Impact of different mass drug adminsitraion strategies for gaining and sustaining control of Schistosoma mansoni and Schistosoma haematobium infection. Am J Trop Med Hyg 103 (Suppl 1): 14-23.

Linehan M, Hanson C, Weaver A, Baker M, Kabore A et al (2011) Integrated implementation of programs targeting neglected tropical diseases through preventive chemotherapy: proving the feasibility at national scale. Am J Trop Med Hyg 84(1):5-14

Moher D, Liberati A, Tetzlaff J, Altman DG, The PRISMA Group (2009) Preferred Reporting Items for Systematic Reviews and Meta-Analyses: The PRISMA Statement. PLoS Med 6(7): e1000097. doi:10.1371/journal.pmed.1000097.

Sterne JA, Hernán MA, Reeves BC, Savović J, Berkman ND, Viswanathan M, Henry D, Altman DG et al. ROBINS-I: a tool for assessing risk of bias in non-randomised studies of interventions. BMJ. 2016;355:i4919. doi: 10.1136/bmj.i4919.

Uniting to Combat NTDs 2012. London Declaration on neglected tropical diseases. http://unitingtocombatntds.org/resource/london-declaration. 
medRxiv preprint doi: https://doi.org/10.1101/2021.05.10.21256643; this version posted May 15, 2021. The copyright holder for this preprint

(which was not certified by peer review) is the author/funder, who has granted medRxiv a license to display the preprint in perpetuity.

It is made available under a CC-BY-NC-ND 4.0 International license .

Vermunt JK, Magidson J. Technical guide for latent GOLD 5.0: basic, advanced, and syntax. Belmont: Statistical Innovations Inc.; 2013. Available from: http://www.statisticalinnovations.com/latent-gold-5-1/.

Von Elm E, Altman DG, Egger M, et al. The Strengthening the Reporting of Observational Studies in Epidemiology (STROBE) statement: guidelines for reporting observational studies. Prev Med 2007;45:247-51.

WHO. Schistosomiasis: Progress Report 2001-2011 and Strategic Plan 2012-2020. 2012a.

WHO. Accelerating work to overcome the global impact of neglected tropical disease: a road map for implementation. 2012b. WHO/HTM/NTD/2012, $37 \mathrm{pp}$.

WHO. Prevention and control of schistosomiasis and soil-transmitted helminthiasis: A Report of WHO Expert Committee. 2006 (WHO Technical Report Series 912) Geneva, P 1-57.

WHO. The control of schistosomiasis: Second report of the WHO Expert Committee (WHO technical report series; 912), 2002. Geneva, P 1-94.

WHO. Report of the WHO Informal Consultation on Schistosomiasis Control. Geneva 2-4 December, 1998;1-44.

WHO. The Control of Schistosomiasis. Second report of the WHO Expert Committee 1993. Technical Report Series No. 830. Geneva.

WHO. The Control of Schistosomiasis: Report of WHO Expert Committee. Technical Report Series

No.

1985;

728.

Geneva. 


\section{APPENDIX 1}

\section{Evidence-to-recommendation table}

PICO

Population

- Whole population or subgroups (Pre-SAC, SAC, adults including pregnant and lactating women) infected with any of the schistosome species or non-infected and living in endemic areas who received PZQ during a PC or any MDA programme

Intervention

- Praziquantel at a single oral dose $(50,60,70$ or $80 \mathrm{mg} / \mathrm{kg}$ or in combination with Albendazole, Mebendazole, Pyrantel pamoate or Levamisole (for soil-transmitted helminthiasis), or Albendazole plus either Ivermectin or Diethylcarbamazine [DEC] (for lymphatic filariasis), ACTs (for malaria), or Azithromycin (Zithromax) for trachoma.

Comparators

- WHO recommended prevalence thresholds for low, moderate and high endemicities

\section{Outcomes}

Primary outcomes

- Post MDA prevalence of infection or percent reduction at well-defined follow-up times

- Post MDA intensity of infection or percent reduction of egg count at well-defined follow-up times

- Post MDA transmission or percent reduction in transmission at well-defined follow-up times Secondary outcomes

- Compliance and acceptance of the intervention by the population.

- Cost effectiveness of the prevalence threshold selected for PC.

- Cost effectiveness of the diagnostic criteria selected for PC.

Benefits and harms (adverse events) 


\section{Evidence-to-recommendation tables}

\begin{tabular}{|c|c|c|c|c|c|}
\hline & $\begin{array}{l}\text { Description of the factor to } \\
\text { consider }\end{array}$ & Criteria & Judgements & Evidence & $\begin{array}{l}\text { Additional } \\
\text { information (by } \\
\text { GDG members) } \\
\end{array}$ \\
\hline $\begin{array}{l}\text { Benefits and } \\
\text { harms }\end{array}$ & $\begin{array}{l}\text { This requires an evaluation of the } \\
\text { absolute effects of both benefits and } \\
\text { harms (or downsides) of the } \\
\text { intervention and their importance. The } \\
\text { greater the net benefit or net harm } \\
\text { associated with an intervention or } \\
\text { exposure, the greater the likelihood of } \\
\text { a strong recommendation in favour or } \\
\text { against the intervention. }\end{array}$ & $\begin{array}{l}\text { Do the desirable } \\
\text { effects outweigh } \\
\text { the undesirable } \\
\text { effects? }\end{array}$ & $\begin{array}{l}\bigotimes \text { Yes } \\
\square \text { No } \\
\square \text { Uncertain }\end{array}$ & $\begin{array}{l}\text { The current systematic review showed high benefit of PZQ at } \\
\text { a single dose of } 40 \mathrm{mg} / \mathrm{kg} \text { in terms of prevalence and } \\
\text { intensity of infection from schistosomiasis PC/MDA. Other } \\
\text { high-quality systematic reviews }(1,2,3,4) \text { and randomised } \\
\text { controlled trials }(5,6) \text { have shown similar results. Systematic } \\
\text { review assessing adverse events associated with PZQ } \\
\text { reported mild to moderate adverse and transient events. None } \\
\text { reported serious events }(1,2,3,4) \text {. }\end{array}$ & $\bullet$ \\
\hline $\begin{array}{l}\text { Values and } \\
\text { Preferences }\end{array}$ & $\begin{array}{l}\text { This describes the relative importance } \\
\text { assigned to health outcomes by those } \\
\text { affected by them; how such } \\
\text { importance varies within and across } \\
\text { populations; and whether this } \\
\text { importance or variability is surrounded } \\
\text { by uncertainty. The less uncertainty or } \\
\text { variability there is about the values and } \\
\text { preferences of people experiencing the } \\
\text { critical or important outcomes, the } \\
\text { greater the likelihood of a strong } \\
\text { recommendation. }\end{array}$ & $\begin{array}{l}\text { Is there } \\
\text { important } \\
\text { uncertainty or } \\
\text { variability about } \\
\text { how much } \\
\text { people value the } \\
\text { options? }\end{array}$ & $\begin{array}{l}\square \text { Major uncertainty } \\
\text { or variability } \\
\bigotimes \text { Minor uncertainty } \\
\text { or variability } \\
\square \text { Unknown }\end{array}$ & $\begin{array}{l}\text { Recent reviews showed that in several communities there } \\
\text { are some concerns on risk of adverse events and also lack } \\
\text { of trust in information. }(1,2) \text { However, studies reporting } \\
\text { MDA showed a high treatment coverage, in general above } \\
\text { the recommended percentage of WHO. }\end{array}$ & $\bullet$ \\
\hline
\end{tabular}




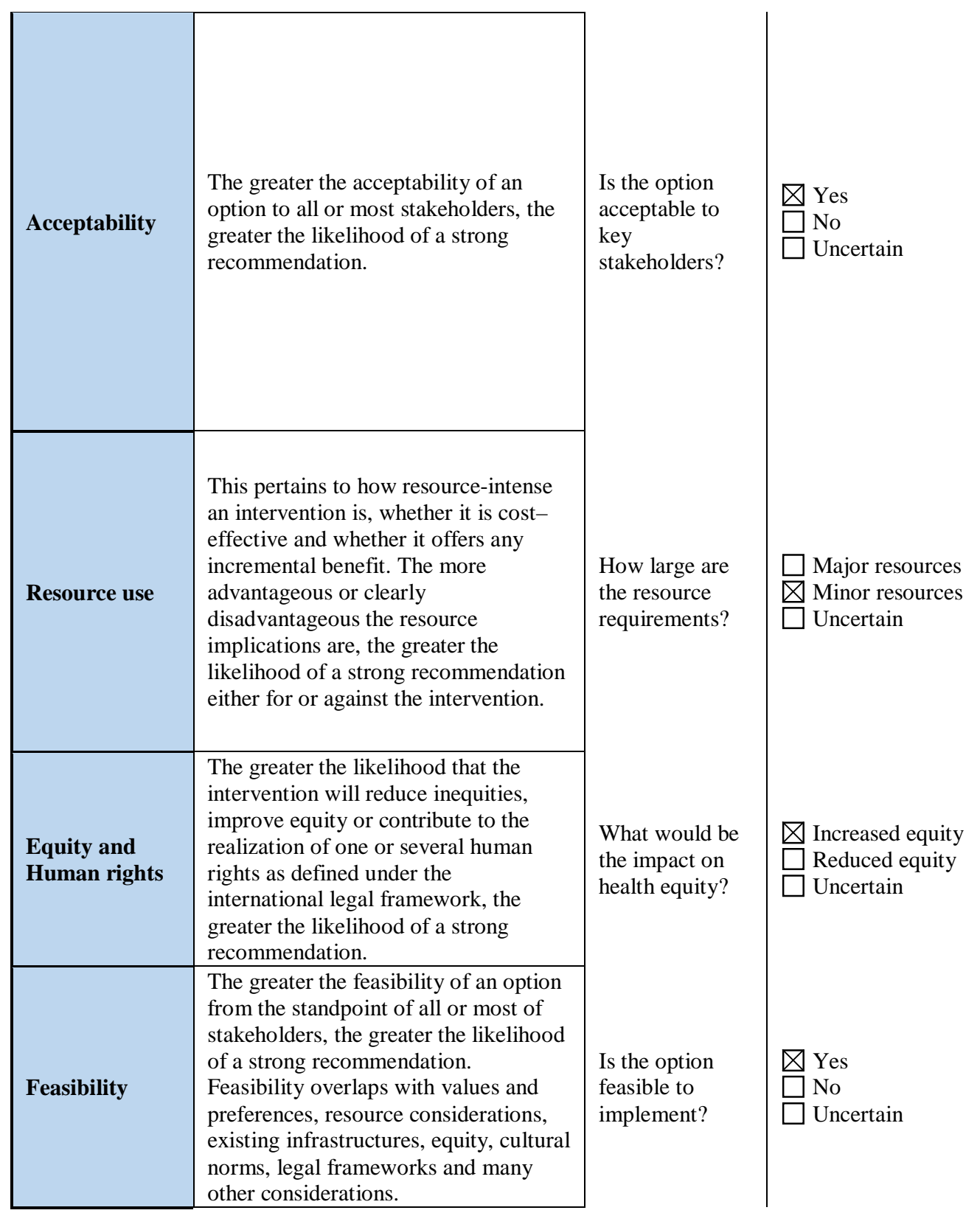

- PZQ can be administered in several formulations for complete acceptability by treated people, including schoolaged children. In fact, it is available also in crushed tablet form and mixed with orange-juice (3). Previous studies have shown that the fruit flavour helped to mask the bitter taste of PZQ (4) and acceptability is high (5)

- Optimal community participation remains challenging, but several studies identified key factors for reaching the target as education, community workers training, praziquante tasting, timing not interfering with agricultural activities, trust in care information and careful consideration of prior adverse events $(1,2,6-8)$

Cost-effectiveness of PZQ MDA is proven by several studies $(3,9-11)$. In one observation treatment costs were estimated at US $\$ 0.74$ for school-aged children and $\$ 1.74$ for preschoolaged children and adults (10) while in another study were US $\$ 0.54$ for school-aged-children (12). In these as in other studies MDA was judge as cost-effective.

The estimated cost from WHO for a single 600-mg tablet is about US\$ 0.08 and an average treatment is estimated to be between US\$ 0.20-0.30.

Praziquantel is now available free of charge to high-disease burden countries in sub-Saharan Africa, through a donation from Merck Serono to the WHO.

The recommendation of scaling-up MDA will end-up with an increased equity in term of access to healthcare and averted life years spent with disability and reduced mortality.

Schistosomiasis does primarily affect low and middle-income countries, and reducing the disease burden would improve equity.

- The intervention is feasible, as shown by the large number of studies in the field and the conduct of MDA program according to the previous WHO guidelines. 


\section{Decision table}

\begin{tabular}{|c|c|c|c|}
\hline Balance of Consequences & $\begin{array}{l}\square \text { Undesirable conseque } \\
\square \text { Undesirable consequeı } \\
\square \text { The balance between c } \\
\square \text { Desirable consequence } \\
\square \text { Desirable consequence }\end{array}$ & $\begin{array}{l}\text { ly outweigh desirable consequences } \\
\text { ably outweigh desirable consequence } \\
\text { and undesirable consequences is clos } \\
\text { y outweigh undesirable consequenc } \\
\text { outweigh undesirable consequences }\end{array}$ & ly balanced or uncertain \\
\hline \multirow[t]{2}{*}{ Type of Recommendation } & \multicolumn{2}{|c|}{$\begin{array}{l}\text { The strength of a recommendation expresses the degree to which the } \\
\text { GDG is confident in the balance between the desirable and undesirable } \\
\text { consequences of implementing the recommendation. When a GDG is } \\
\text { very certain about this balance (i.e. the desirable consequences clearly } \\
\text { outweigh the undesirable consequences), it issues a strong } \\
\text { recommendation in favour of an intervention. When it is uncertain } \\
\text { about this balance, however, it issues a conditional (or "weak") } \\
\text { recommendation. } \\
\text { Policy-makers: }\end{array}$} & \multirow[t]{2}{*}{$\begin{array}{l}\bigotimes \text { Strong recommendation for } \\
\square \text { Conditional recommendation for } \\
\qquad \text { Only in specific context } \\
\square \text { Strong recommendation against } \\
\square \text { Conditional recommendation against __ } \\
\square \text { No recommendation can be made because } \\
\text { evidence of the effectiveness or harm of __ was } \\
\text { not identified. }\end{array}$} \\
\hline & Strong recommendation & Conditional recommendation & \\
\hline
\end{tabular}




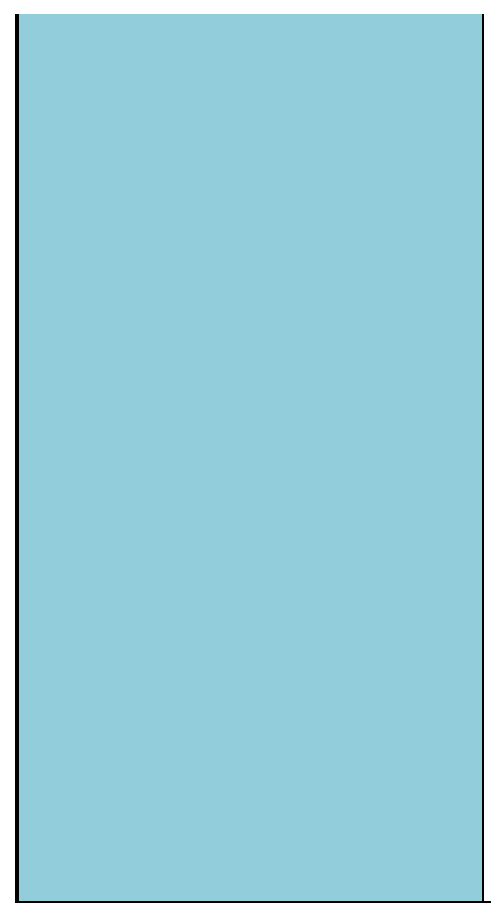

The recommendation can be
adopted as policy in most

situations.
Policy-making will require

substantial debate and

involvement of various

stakeholders.
More data from low, moderate and high endemicity settings are needed to update the evidence.

Need to strengthen the key factors for treatment compliance such as education, training of personnel program and increase of adequate information to communities. 
medRxiv preprint doi: https://doi.org/10.1101/2021.05.10.21256643; this version posted May 15, 2021. The copyright holder for this preprint

(which was not certified by peer review) is the author/funder, who has granted medRxiv a license to display the preprint in perpetuity.

It is made available under a CC-BY-NC-ND 4.0 International license .

\section{References- evidence to recommendations}

1. Krentel A, Fischer PU, Weil GJ. A Review of Factors That Influence Individual Compliance with Mass Drug Administration for Elimination of Lymphatic Filariasis. PLoS Neg1 Trop Dis. 2013;

2. Shuford K V., Turner HC, Anderson RM. Compliance with anthelmintic treatment in the neglected tropical diseases control programmes: A systematic review. Parasites and Vectors. 2016.

3. WHO. Preventive chemotherapy in human helminthiasis: a manual for health professionals and programme managers. Use of Anthelminthic Drugs in Control. 2006.

4. Korenromp EL, Arnold F, Williams BG, Nahlen BL, Snow RW. Monitoring trends in under-5 mortality rates through national birth history surveys. Int J Epidemiol. 2004;

5. Namwanje H, Kabatereine NB, Olsen A. The acceptability and safety of praziquantel alone and in combination with mebendazole in the treatment of Schistosoma mansoni and soil-transmitted helminthiasis in children aged 1-4 years in Uganda. Parasitology. 2011;

6. Katsivo MN, Muthami LN, Kimani S, Karama M, Kingori F. Involvement of a community in schistosomiasis control: a Kenyan experience. East Afr Med J. 1993;

7. Knopp S, Person B, Ame SM, Ali SM, Muhsin J, Juma S, et al. Praziquantel coverage in schools and communities targeted for the elimination of urogenital schistosomiasis in Zanzibar: A cross-sectional survey. Parasites and Vectors. 2016;

8. Chami GF, Kontoleon AA, Bulte E, Fenwick A, Kabatereine NB, Tukahebwa EM, et al. Profiling Nonrecipients of Mass Drug Administration for Schistosomiasis and Hookworm Infections: A Comprehensive Analysis of Praziquantel and Albendazole Coverage in Community-Directed Treatment in Uganda. Clin Infect Dis. 2016;

9. Lo NC, Lai YS, Karagiannis-Voules DA, Bogoch II, Coulibaly JT, Bendavid E, et al. Assessment of global guidelines for preventive chemotherapy against schistosomiasis and soil-transmitted helminthiasis: a cost-effectiveness modelling study. Lancet Infect Dis. 2016;

10. Lo NC, Bogoch II, Blackburn BG, Raso G, N'Goran EK, Coulibaly JT, et al. Comparison of community-wide, integrated mass drug administration strategies for schistosomiasis and soiltransmitted helminthiasis: A cost-effectiveness modelling study. Lancet Glob Heal. 2015;3(10):e629_ 38.

11. Cioli D, Pica-Mattoccia L, Basso A, Guidi A. Schistosomiasis control: Praziquantel forever? Molecular and Biochemical Parasitology. 2014.

12. Brooker S, Kabatereine NB, Fleming F, Devlin N. Cost and cost-effectiveness of nationwide schoolbased helminth control in Uganda: Intra-country variation and effects of scaling-up. Health Policy Plan. 2008; 